\title{
Results of Work of the Raptor Ringing Center of the Russian Raptor Research and Conservation Network in 2014
}

\section{РЕЗУЛЬТАТЫ РАБОТЫ ЦЕНТРА КОЛЬЦЕВАНИЯ ХИЩНЫХ ПТИЦ РОССИЙСКОЙ СЕТИ ИЗУЧЕНИЯ И ОХРАНЫ ПЕРНАТЫХ ХИЩНИКОВ В 2014 ГОДУ}

\author{
Karyakin I.V. (Center of Field Studies, N. Novgorod, Russia), \\ Bekmansurov R.H. (Elabuga Institute, Kazan Federal University; NP "Nizhnyaya Kama", \\ Elabuga, Republic of Tatarstan, Russia), \\ Babushkin M.V. (Darwin State Nature Biosphere Reserve, Cherepovets, Russia) \\ Vazhov S.V., Bachtin R.F. (The Shukshin Altai State Academy of Education, Biysk, Russia) \\ Nikolenko E.G., Shnayder E.P. (LLC Sibecocenter, Berdsk, Novosibirsk region, Russia) \\ Pimenov V.N. (Volgograd branch of the Russian Bird Conservation Union, Volzhskiy, \\ Volgograd district, Russia)
}

Карякин И.В. (Центр полевых исследований, Н.Новгород, Россия), Бекмансуров Р.X. (Елабужский институт Казанского федерального университета; Национальный парк «Нижняя Кама», Елабуга, Республика Татарстан, Россия), Бабушкин М.В. (Дарвинский государственный природный биосферный заповедник, Череповец, Россия) Важов С.В., Бахтин Р.Ф. (Алтайская государственная академия образования им. В.М. Шукшина, Бийск, Россия) Николенко Э.Г., Шнайдер Е.П. (ООО «Сибэкоцентр», Бердск, Новосибирская область, Россия)

Пименов В.Н. (Волгоградское отделение Союза охраны птиц России, Волжский, Волгоградская область, Россия)

\section{Контакт \\ Игорь Карякин Центр полевых иссиедований 603109, Россия, Нижний Новгород, ул. Нижегородская, 3-29 \\ тел.: +78314333847 ikar_research@mail.ru \\ Ринур Бекмансуров, Елабужский институт Казанского федераиь- ного университета; Национамьный парк "Нижняя Кама", 423607, Россия, Республика Татарстан, г. Елабуга, ул. Казанская, 89, тел.: +785557 75455 rinur@yandex.ru}

Мирослав Бабушкин $\triangle$ Арвинский заповедник 162606, Россия, Вологодская область, г. Череповец, пр. Победы, 6-3 тел.: +78202 570258 babushkin02@mail.ru

\section{Резюме}

В работе Центра кольцевания хищных птиц Российской сети изучения и охраны пернатых хишников в 2014 году участвовали 39 орнитологов-исследователей и любителей птиц, которые в общей сложности окольцевами 889 особей 23 видов соколообразных и сов. Из меченых птиц мидируют курганник мохноногий (Вutео hemilasius) - 154 особи, орёл-могильник (Aquila heliaca) - 110 особей, орёл степной (Aquila nipalensis) - 95 особей, курганник (Buteo rufinus) - 87 особей, орлан-белохвост (Haliaeetus albicilla) - 78 особей. За 2014 г. и первые 5 месяцев 2015 г. получена инсормация о регистрации 50 птиц с кольцами, из которых 39 удалось идентисицировать. Среди идентисицированных птиц с кольцами кидируют орлы-могильники (14 особей) и орланы-белохвосты (9 особей).

Киючевые слова: пернатые хищники, хишные птицы, цветное мечение, кольцевание.

Поступияа в реАакцию: 15.08 .2015 г. Принята к публикации: 11.11 .2015 г.

\begin{abstract}
In work of the Raptor Ringing Center of the Russian Raptor Research and Conservation Network in 2014 participated 39 ornithologists-researchers and birdwatchers who have ringed in total 889 individuals of 23 species of birds of prey (Falconiformers) and owls. From colour marked birds the leaders are Upland Buzzard (Buteo hemilasius) - 154 ind., Eastern Imperial Eagle (Aquila heliaca) - 110 ind., Steppe Eagle (Aquila nipalensis) - 95 ind., LongLegged Buzzard (Buteo rufinus) - 87 ind., White-Tailed Eagle (Haliaeetus albicilla) - 78 ind. For 2014 and the first 5 months of 2015 the information was received about the registration of 50 birds with rings from which 39 birds were identified. Among returns the leaders are Eastern Imperial Eagle (14 ind.) and White-Tailed Eagle (9 ind.). Keywords: birds of prey, raptors, colour ringing, tagging.
\end{abstract} Received: 15/08/2015. Accepted: 11/11/2015.

DOI: $10.19074 / 1814-8654-2015-30-31-61$

\section{Введение}

Программа цветного мечения хишных птиц Российской сети изучения и охраны пернатых хишников (Аалее RRRCN) была начата в 2012 г. с реализации проектов в ряде регионов России и Казахстана (Бекмансуров и Ар., 2012). В рамках про-

\section{Introduction}

The program of color marking of raptors in the Russian Raptor Research and Conservation Network (further RRRCN) began in 2012 with realization of projects in a number of Russian regions and Kazakhstan (Bekmansurov et al., 2012). Within the limits 
Сергей Важов Алтайская государственная акамемия образования им. В.М. Шукшина, 659333, Россия, Алтайский край, г. Бийск, ул. Короленко, 53 тел.: +79635348107 aquila-altai@mail.ru

Роман Бахтин

Алтайская государственная акацемия образования им. В.М. Шукшина, al.raptors@yandex.ru

Эльвира Николенко ООО “Сибэкоцентр" 630090, Россия, Новосибирск, а/я 547 тел.: +79231501279 elvira_nikolenko@mail.ru

Елена Шнайдер ООО "Сибэкоцентр" 630090, Россия, Новосибирск, а/я 547 тел: +79137956549 equ001@gmail.com

Вачерий Пименов Волгограсское отделение Союза охраны птиц России pimenova@inbox.ru

\section{Contact:}

Igor Karyakin Center of Field Studies Nizhegorodskaya str. 3-29

Nizhniy Novgorod, Russia, 603109 tel.: +78314333847 ikar_research@mail.ru

Rinur Bekmansurov, Elabuga Institute, Kazan Federal University; National Park

"Nizhnyaya Kama" Kazaknskaya str., 89 Elabuga Republic of Tatarstan Russia, 423600 tel.: +785557 75455 rinur@yandex.ru

Miroslav Babushkin Darwin State Nature Biosphere Reserve Pobeda ave., 6-3, Cherepovets,

Vologda region,

Russia, 162606

tel.: +78202570258

babushkin02@mail.ru граммы были разработаны цветные схемы мечения хишных птиц, согласованные с национальными координаторами в Европе и Азии, налажена закупка цветных пластиковых колец, на которых указан амрес сайта WWW.RRRCN.RU, создана Веб-ГИС "Кольцевание" с обшим Аоступом к информации пользователей сети Интернет, на сайте RRRCN размешена онлайн-форма мяя сообшения о встречах окольцованных птиц, создана специальная ветка форума RRRCN мия анонсирования и обсуждения этих случаев. В 2013 г. программа была поццержана Русским геограсическим обшеством - проект "Орлы России", - что Аало программе Аополнительный толчок к развитию (Николенко, 2013). В 20132014 г. в рамках совместной работы с национаяьными центрами кольцевания налажен выпуск алюминиевых колец с $\Delta$ войным прокрашенным кодом и алюминиевых цветных колец для мечения крупных птиц.

Программа цветного мечения хишных птиц развивается, к ней подкиючаются новые регионы, в ней появляются новые схемы. $\Delta$ ия Аоведения $А$ орнитологов актуаьной инсормации о программе и её результатах, мы планируем публиковать регулярные обзоры. В Аанном обзоре обобшены результаты программы и её обновления за 2014 год, а информация о возвратах приводится $\Delta \mathrm{O} 1$ июня 2015 г. вкиючительно.

\section{Результаты программы \\ Кольца}

В рамках совместных проектов RRRCN с национальными центрами кольцевания птиц с 2013 г. начами внеАряться в практику мечения крупных хишных птиц в качестве стандартных национамьных колец алюминиевые кольца нового образца на закиёпках, с прокрашенным в чёрный цвет $\Delta$ войным буквенно-числовым кодом ${ }^{31}$. Эти кольца более удобны как мяя птиц, так и мяя кольцевателей. Менее широкий, чем замок, крепежный выступ кольца более безопасен ммя киамки - вероятность повредить скорлупу яйца острым краем замка у наседки меньше, если она окольцована кольцами нового образца на киёпках. Эти кольца более удобно надевать, особенно работая с птицами на гнезде, используя Аве киёпки и специальный инструмент - втягиваюший закиёпочник (рис. 1) Закиёпочник продаётся во многих строительных и инструментаиьных магазинах, of the program color marking schemes for raptors, agreed with national coordinators in Europe and Asia have been developed, and the Web-GIS "Ringing" was created with the general access to the user information of Internet, on site RRRCN the online form was placed for the messages about meeting ringed birds, the special branch at forum RRRCN was created for illumination of the information on returns and meetings of ringed birds, the purchase of color plastic rings with the site address WWW. RRRCN.RU was adjusted. In 2013 the program was supported by Russian geographical society within the limits of the project "Eagles of Russia," therefore the program has received an additional push to development (Nikolenko, 2013). In 2013-2014 within the limits of teamwork with the national ringing centers began release of aluminum rings with the double painted code and aluminum color rings for marking the large birds was adjusted.

The program of color marking of raptors is developing, new regions are joining it, and new schemes are appearing in it. For bringing to ornithologists the actual information on the program and its results, we plan to publish regular reviews. In the given review the results of the program and its updating for 2014 are generalized, and the information on returns is resulted till June, $1^{\text {st }}, 2015$ inclusive.

\section{Results of the program Rings}

Within the limits of joint projects RRRCN with the national ringing centers of birds since 2013 started to intrude in practice the marking of large raptors with a new sample of riveted aluminum rings with double painted black color literal-numerical code as the standard national rings ${ }^{31}$. These rings are more convenient both for birds, and for ringers. Less wide, than the lock, a fixing ledge of a ring is safer for eggs of birds probability to damage an egg-shell with a keen edge of the lock for a brood hen less, if it ringed with the new riveted sample. These rings are more convenient for putting on, especially when working with birds on a nest, using two rivetings and the special tool - drawing in riveting hammer (fig. 1). Riveting hammer is on sale in many hardware and tool stores, and can be ordered in any large Internet shop. At last the height of rings allows placing larger elements of a code on them which are visible from apart. 
Sergey Vazhov

The Shukshin Altai State

Academy of Education,

Korolenko str., 53

Biysk, Altai Kray,

Russia, 659333

tel.: +79635348107

aquila-altai@mail.ru

Roman Bachtin

The Shukshin Altai State

Academy of Education,

al.raptors@yandex.ru

Elvira Nikolenko

LLC Sibecocenter

P.O. Box 547,

Novosibirsk

Russia, 630090

tel: +79231501279

elvira_nikolenko@mail.ru

Elena Shnayder

LLC Sibecocenter

P.O. Box 547,

Novosibirsk

Russia, 630090

tel.: +79137956549

equ001@gmail.com

Valeriy Pimenov

Volgograd branch of the

Russian Bird Conserva-

tion Union

pimenova@inbox.ru

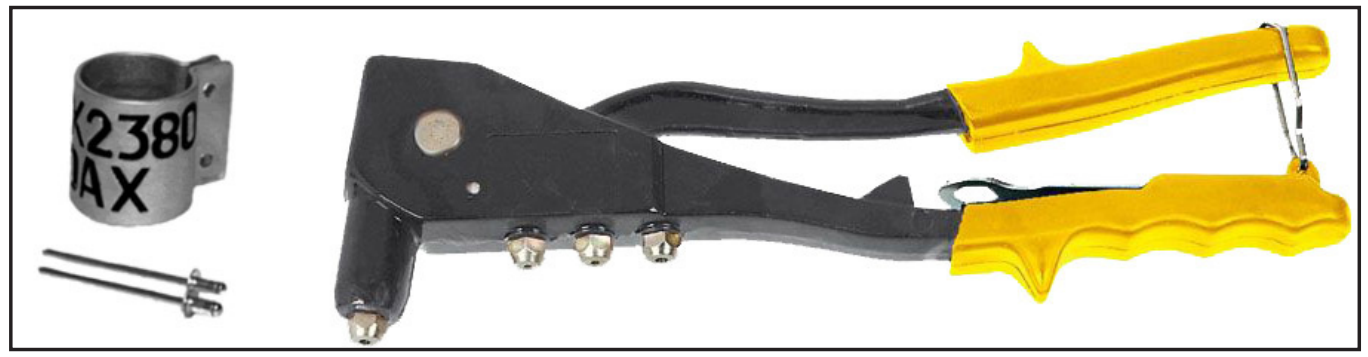

Рис. 1. Кольцо на киёпках с двойным прокрашенным кодом и закиёпочник.

Fig. 1. Rivet ring with a double black colored code and blind river tongs.

может быть заказан в кюбом крупном интернет-магазине. Наконец высота колец позволяет на них разместить более крупные элементы кода, которые видны издаиека. Авойной код позволяет, Ааже при наблюдении части кольца, ограничить круг поиска окольцованной птицы в базе Аанных десятью особями и не зная полного кода более точно локамизовать место кольцевания птицы.

Аля мечения орлов в России, в соответствии со стандартом Российского центра кольцевания, приняты серии АВ (Аля размерного киасса 25,5×35,0 мм) и АА ( $и я$ размерного киасса $22,5 \times 35,0$ мм). Всё поле кольца занимает код: в верхней части - основной буквенно-цифровой код - например, АВ 0010, а ниже него - Аополнительный цифровой коА - например, ОА. Аополнительный цифровой код определяет каждую десятку и сотню колец (цисра обозначает код десятки колец с 0 Ао 9, а буква - код сотни колец - A, B, C, D, E, F, G, H, K, L). Аанные центра кольцевания выгравированы поперёк тела кольца со стороны замка: с одной стороны WWW. RRRCN.RU, a с Аругой - Moscow Russia.

Аля мечения орлов в Казахстане в соответствии со стандартом Казахстанского центра кольцевания приняты серии АК (Аля размерного киасса 25,5×35,0 мм) и ВК (Аля размерного киасса $22,5 \times 35,0$ мм). В верхней части кольца выгравированы данные центра кольцевания - WWW.RRRCN. RU Kazakhstan Almaty, ниже которых располагается основной буквенно-цисровой код - например, АK 1010, а ниже него Аополнительный цисрровой коА - например, 1М. Аополнительный цисровой код определяет каждую десятку и сотню колец (цисра обозначает коА Аесятки колец с 0 $\Delta$ о 9, а буква - код сотни колец - M, N, P, R, S, T, U, V, W, X).

В программе цветного мечения дия кольцевания хишных птиц размерного киасса от большого подорлика (Aquila clanga), скопы (Pandion haliaetus) и меньше исполь-
The double code allows, even at supervision of a part of a ring, limiting a search circle of ringed birds in a database to ten individuals and without knowing a full code more precisely localize a place of ringed birds.

For ringing the eagles in Russia according to the standard of the Russian ringing center series $A B$ (for a dimensional class $25.5 \times 35.0 \mathrm{~mm}$ ) and AA (for a dimensional class $22.5 \times 35.0 \mathrm{~mm}$ ) are accepted. All field of a ring occupies a code: in the top part the basic alphanumeric code - for example, $A B$ 0010, and below it - an additional digital code - for example, OA. The additional digital code defines every ten and hundred rings (the digit marks a code of ten rings from 0 to 9 , and a letter - a code of hundred rings - A, B, C, D, E, F, G, H, K, L). The center ringing data is engraved across a body of a ring from the side of the lock: on the one hand WWW.RRRCN.RU, and on another - Moscow Russia.

For ringing the eagles in Kazakhstan according to the standard of the Kazakhstan ringing center series $A K$ (for a dimensional class $25.5 \times 35.0 \mathrm{~mm}$ ) and BK (for a dimensional class $22.5 \times 35.0 \mathrm{~mm}$ ) are accepted. In the top part of a ring the ringing center data is engraved - WWW.RRRCN.RU Kazakhstan Almaty, below which the basic alphanumeric code is situated - for example AK 1010, and below it - an additional digital code - for example, $1 \mathrm{M}$. The additional digital code defines every ten and hundred rings (the digit marks a code of ten rings from 0 to 9 , and a letter - a code of hundred rings $-\mathrm{M}, \mathrm{N}, \mathrm{P}, \mathrm{R}, \mathrm{S}, \mathrm{T}, \mathrm{U}, \mathrm{V}, \mathrm{W}, \mathrm{X}$ ).

In the program of color ringing of raptors for a dimensional class from Greater Spotted Eagle (Aquila clanga), Osprey (Pandion haliaetus) and less plastic rings by analogy to current programs of color marking in Europe are used. However in ringing large eagles and sea eagles we almost completely have passed to use of aluminum rings that essentially reduces loss of a color ring by birds as a result of its destruction by the 
Табл. 1. Размерные киассы пластиковых и аиюминиевых колец Российской сети изучения и охраны пернатых хишников.

Table 1. Sizes of plastic and aluminum rings of the Russian Raptor Research and Conservation Network.

\begin{tabular}{|c|c|c|}
\hline $\begin{array}{l}\text { Размер (внутренний } \\
\text { диаметр × высота, мм) } \\
\text { Size (inner diameter × } \\
\text { height, } \mathrm{mm} \text { ) }\end{array}$ & $\begin{array}{l}\text { Серия } \\
\text { Series }\end{array}$ & $\begin{array}{r}\text { Bим } \\
\text { Species } \\
\end{array}$ \\
\hline $25.5 \times 35.0$ & $\begin{array}{r}\text { Пластик / Plastic } \\
\text { A, F } \\
\text { Алюминий / Aluminum } \\
\text { AB, AK, B }\end{array}$ & $\begin{array}{r}\text { Беркут / Golden Eagle (Aquila chrysaetos), } \\
\text { орёл-могильник / Imperial Eagle (Aquila heliaca) - самка / female, } \\
\text { степной орёл / Steppe Eagle (Aquila nipalensis) - самка / female, } \\
\text { гриср / Cinereous Black Vulture (Aegypius monachus) }\end{array}$ \\
\hline $22.5 \times 35.0$ & $\begin{array}{r}\text { Пластик / Plastic } \\
\text { B, H } \\
\text { А^юминий / Aluminum } \\
\text { AA, BK, C }\end{array}$ & $\begin{array}{r}\text { Орёл-могильник (Aquila heliaca) - самец, степной орёл / Imperial Eagle (Aq- } \\
\text { uila nipalensis) - самец / male, силин / Eagle Owl (Bubo bubo) }\end{array}$ \\
\hline $25.5 \times 30.0$ & $\begin{array}{r}\text { Алюминий / Aluminum } \\
\qquad \mathrm{AB}, \mathrm{A}, \mathrm{M}\end{array}$ & Орлан-белохвост / White-Tailed Eagle (Haliaeetus albicilla) \\
\hline $16.0 \times 23.0$ & $\begin{array}{r}\text { Пластик / Plastic } \\
\text { E, F, J, I, L }\end{array}$ & $\begin{array}{l}\text { Скопа / Osprey (Pandion haliaetus), } \\
\text { змеeял / Short-Toed Eagle (Circaetus gallicus) }\end{array}$ \\
\hline $\begin{array}{l}16.0 \times 36.0 \\
16.0 \times 35.0\end{array}$ & $\begin{array}{r}\text { Пластик / Plastic } \\
\text { A, B, C, D, E } \\
\text { Алюминий / Aluminum } \\
\text { AC, D }\end{array}$ & $\begin{array}{l}\text { Большой подорлик / Greater Spotted Eagle (Aquila clanga), } \\
\text { мамый подорлик / Lesser Spotted Eagle (Aquila pomarina) }\end{array}$ \\
\hline $15.5 \times 22.0$ & $\begin{array}{r}\text { Пластик / Plastic } \\
\text { C }\end{array}$ & $\begin{array}{r}\text { Мохноногий курганник / Upland Buzzard (Buteo hemilasius), } \\
\text { орёл-карлик / Booted Eagle (Hieraaetus pennatus), } \\
\text { бородатая неясыть / Great Grey Owl (Strix nebulosa) }\end{array}$ \\
\hline $14.5 \times 18.0$ & $\begin{array}{r}\text { Пластик / Plastic } \\
\text { M }\end{array}$ & Аииннохвостая неясыть / Ural Owl (Strix uralensis) \\
\hline $12.5 \times 22.0$ & $\begin{array}{r}\text { Пластик / Plastic } \\
\text { D, N }\end{array}$ & $\begin{array}{r}\text { Курганник / Long-Legged Buzzard (Buteo rufinus), зимняк / Rough-Legged Buz- } \\
\text { zard (Buteo lagopus), канюк / Common Buzzard (Buteo buteo), тетеревятник / } \\
\text { Goshawk (Accipiter gentilis), коршун / Black Kite (Milvus migrans), балобан / Saker } \\
\text { Falcon (Falco cherrug), сапсан / Peregrine Falcon (Falco peregrinus) }\end{array}$ \\
\hline $11.0 \times 35.0$ & $\begin{array}{r}\text { Пластик / Plastic } \\
\text { K }\end{array}$ & $\begin{array}{r}\text { Болотный мунь / Marsh Harrier (Circus aeruginosus), } \\
\text { полевой мунь / Hen Harrier (Circus cyaneus) }\end{array}$ \\
\hline $7.0 \times 20.0$ & $\begin{array}{r}\text { Пластик / Plastic } \\
\text { L }\end{array}$ & $\begin{array}{r}\text { Ауговой ^унь / Montagu's Harrier (Circus pygargus), } \\
\text { степной ^унь / Pallid Harrier (Circus macrourus) }\end{array}$ \\
\hline $7.0 \times 18.0$ & $\begin{array}{r}\text { Пластик / Plastic } \\
\text { Y, V, U }\end{array}$ & $\begin{array}{l}\text { Перепелятник / Sparrowhawk (Accipiter nisus), } \\
\text { пустельга обыкновенная / Kestrel (Falco tinnunculus), }\end{array}$ \\
\hline $7.0 \times 13.0$ & $\begin{array}{r}\text { Пластик / Plastic } \\
\text { X }\end{array}$ & $\begin{array}{l}\text { Сова ушастая / Long-Eared Owl (Asio otus), } \\
\text { сова болотная / Short-Eared Owl (Asio flammeus) }\end{array}$ \\
\hline $7.0 \times 11.0$ & $\begin{array}{r}\text { Пластик / Plastic } \\
\text { W }\end{array}$ & $\begin{array}{r}\text { Мохноногий сыч / Tengmalm's Owl (Aegolius funereus), } \\
\text { сплюшка / Scops Owl (Otus scops) }\end{array}$ \\
\hline $6.5 \times 15.0$ & $\begin{array}{r}\text { Пластик / Plastic } \\
\text { Z }\end{array}$ & $\begin{array}{r}\text { Чеглок / Hobby (Falco subbuteo), дербник / Merlin (Falco columbarius), кобчик / } \\
\text { Red-Footed Falcon (Falco vespertinus), амурский кобчик / Amur Falcon (Falco amu- } \\
\text { rensis), степная пустельга / Lesser Kestrel (Falco naumanni) }\end{array}$ \\
\hline
\end{tabular}

зуются пластиковые кольца по аналогии с текушими программами цветного мечения в Европе. Однако в кольцевании крупных орлов и орланов мы практически полностью перешли на использование аяюминиевых колец, что сушественно сокрашает потерю птицами цветного кольца в результате его разрушения самой птицей, мибо при внешнем воздействии. В 2014 г. нам УАалось налалить внутри России (в Казани) производство амюминиевых колец на киёпках с двойным кодом, как цветных, так и стандартных. В результате этого мы частично отказаяись от импорта, тем самым сократив себестоимость кольцевания крупных хищников.

Аия ряАа виАОв, в частности Аииннохвостой неясыти (Strix uralensis), ушастой и болотной bird itself, or by external influence. In 2014 we managed to adjust in Russia (in Kazan) manufacture of aluminum riveted rings with a double code, both color and standard. As a result we have partially refused import, thereby having reduced the cost price of ringing large raptors.

For a number of species, in particular Ural Owl (Strix uralensis), Long-Eared and ShortEared Owls (Asio otus, A. flammeus), Boreal Owl (Aegolius funereus) and Scops Owl (Otus scops) the sizes of rings have been reconsidered and new standards were accepted (table 1).

\section{Color schemes}

In addition to 4 regional schemes in Russia (the Yamal, Volga-Ural region, the Lower 
Рис. 2. Регионаиьные и повидовые схемы цветного мечения хишных птиц в 2014 г.

Fig. 2. Regional and species raptor colour ringing schemes in 2014.

сов (Asio otus, A. flammeus), мохноногого сыча (Aegolius funereus) и сплюшки (Otus scops) размеры колец были пересмотрены и приняты новые стандарты (табл. 1).

\section{Цветовые схемы}

В дополнении к 4-м регионаиьным схемам в России (Ямал, Волго-Ураиьский регион, Нижневолжский регион, АлатеСаянский регион) и к 4-м - в Казахстане (Западный Казахстан, Северный Казахстан, Восточный Казахстан, Юго-Восточный
Volga region, the Altai-Sayan region) and to 4 - in Kazakhstan (Western Kazakhstan, Northern Kazakhstan, Eastern Kazakhstan, Southeast Kazakhstan), since 20148 more color ringing schemes of raptors for 7 regions of Russia (Northwest of Russia, Karelia, the Arkhangelsk region, Kalmykia, Middle Ural and Trans-Urals, the Novosibirsk region, the Baikal region) and 1 - for Kazakhstan (Southern Kazakhstan) (table 2, fig. 2) are developed. Also the color ringing schemes of Osprey and Greater Spotted

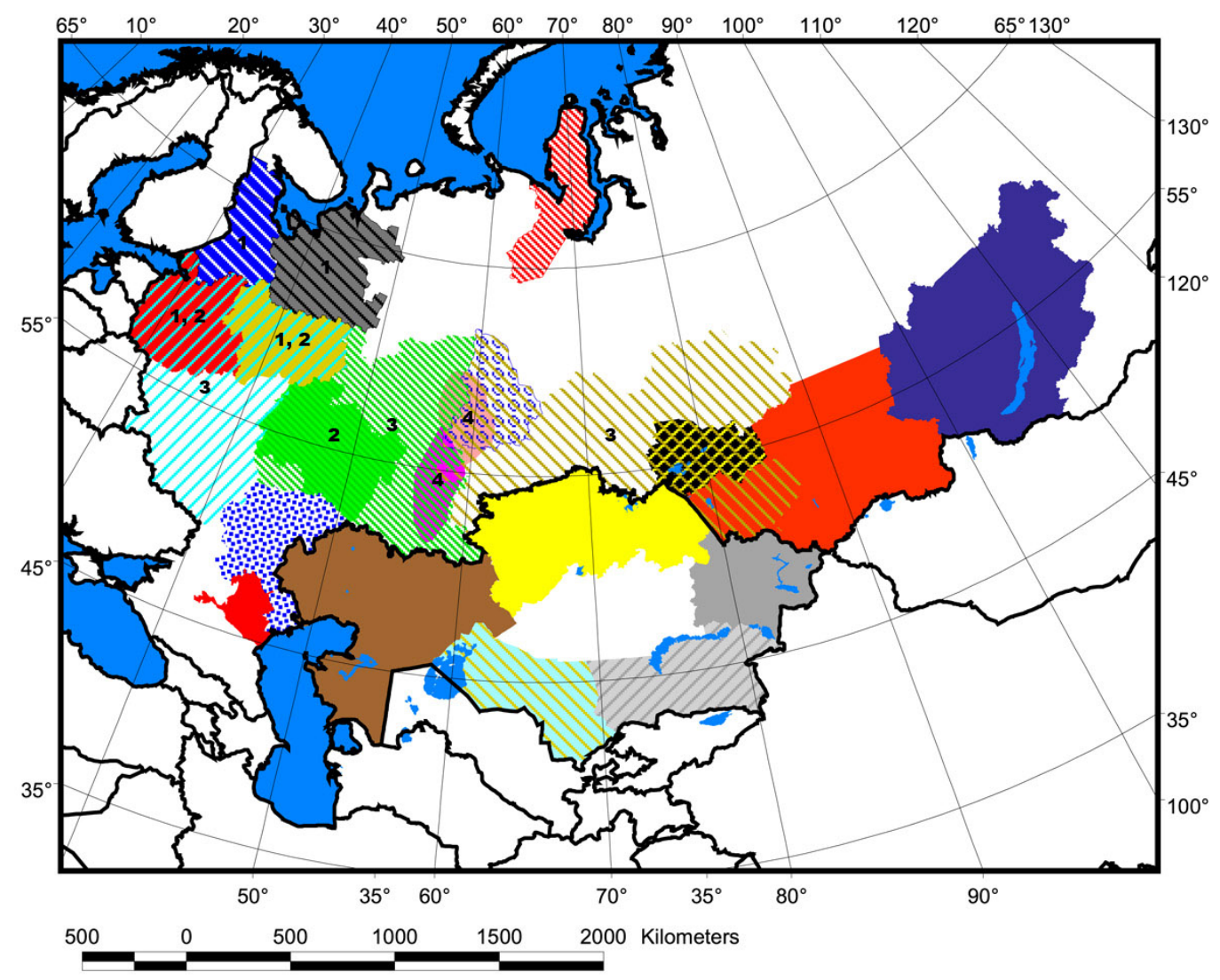

Границы стран / Country borders

Европейская часть России / European part of Russia

Западная Сибирь / Western Siberia

)

Архангельская область / Arkhangelsk district

Республика Карелия / Republic of Karelia

Северо-Запад России / North-West of Russia

Ямал / Yamal

Волго-Уральский регион / Volga-Ural Region

Верхняя Волга / Upper Volga

Средняя Волга / Middle Volga

Fі: Нижняя Волга / Lower Volga

60 Средний Урал и Зауралье ( Свердловская область) / Middle Ural and Trans-Ural ( Sverdlovsk region)

Средний Урал / Middle Ural

Южный Урал / Southern Ural

Республика Калмыкия / Republic of Kalmykia

Новосибирская область / Novosibirsk region

Алтае-Саянский регион / Altai-Sayan region

Байкальский регион / Baikal Region

Северный Казахстан / Northern Kazakhstan

Западный Казахстан / Western Kazakhstan

Восточный Казахстан / Eastern Kazakhstan

Юго-Восточный Казахстан / South-Eastern Kazakhstan
Видовые схемы кольцевания:

1 - Скопа (Pandion haliaetus)

2 - Орлан-белохвост (Haliaeetus albicilla)

3 - Большой подорлик (Aquila clanga)

4 - Сапсан (Falco peregrinus)

\footnotetext{
Южный Казахстан / Southern Kazakhstan
} 
Табл. 2. Регионаиьные и повидовые схемы цветного мечения хишных птиц в России и Казахстане в 2014 .

Table 2. Regional and species raptor colour ringing schemes in Russia and Kazakhstan in 2014.

\begin{tabular}{|c|c|c|c|c|c|c|}
\hline & & & Мевая мапа / Le & ft leg & Правая мапа / R & Right leg \\
\hline $\begin{array}{l}\text { Cтрана } \\
\text { Country }\end{array}$ & $\begin{array}{l}\text { Pernoн } \\
\text { Region }\end{array}$ & $\begin{array}{l}\text { Bus } \\
\text { pecies }\end{array}$ & $\begin{array}{l}\text { Oписание } \\
\text { Description }\end{array}$ & $\begin{array}{l}\text { Puc. } \\
\text { Fig. }\end{array}$ & $\begin{array}{l}\text { Oписание } \\
\text { Description }\end{array}$ & $\begin{array}{l}\text { Puc. } \\
\text { Fig. }\end{array}$ \\
\hline 1 & $\mathbf{2}$ & 3 & 4 & 5 & 6 & $\mathbf{7}$ \\
\hline & Регис & ональные схемы ко & ольцевания / Regic & onal $r$ & & \\
\hline $\begin{array}{l}\text { Россия } \\
\text { Russia }\end{array}$ & $\begin{array}{l}\text { Северо-Запах (Ленинграх- } \\
\text { ская, Псковская, Новгород- } \\
\text { ская, Тверская области) } \\
\text { North-West of Russia (Lenin- } \\
\text { grad, Pskov, Nodgorod and } \\
\text { Tver districts) }\end{array}$ & $\begin{array}{l}\text { Все виды хиш- } \\
\text { ных птиц, кроме } \\
\text { скопы и большо- } \\
\text { го подорлика } \\
\text { All raptors, ex- } \\
\text { cept the Osprey } \\
\text { and Greater } \\
\text { Spotted Eagle }\end{array}$ & $\begin{array}{l}\text { Алюминиевое } \\
\text { кольцо на киёп- } \\
\text { ках красное с } \\
\text { Авойным чёр- } \\
\text { ным кодом } \\
\text { Aluminum } \\
\text { rivet ring red } \\
\text { coloured with } \\
\text { double black } \\
\text { code }\end{array}$ & & $\begin{array}{l}\text { Метамическое } \\
\text { кольцо РЦК или } \\
\text { амюминиевое } \\
\text { кольцо RRRСN } \\
\text { на киёпках с } \\
\text { Авойным чёр- } \\
\text { ным кодом } \\
\text { Metal ring of } \\
\text { national ringing } \\
\text { center or alu- } \\
\text { minum rivet ring } \\
\text { of the RRRCN } \\
\text { with double } \\
\text { black code }\end{array}$ & \\
\hline $\begin{array}{l}\text { Россия } \\
\text { Russia }\end{array}$ & $\begin{array}{l}\text { Карелия (Республика Kape- } \\
\text { лия) } \\
\text { Karelia (Republic of Karelia) }\end{array}$ & $\begin{array}{l}\text { Все виды хищ- } \\
\text { ных птиц, кроме } \\
\text { скопы } \\
\text { All raptors, ex- } \\
\text { cept the Osprey }\end{array}$ & $\begin{array}{l}\text { Алюминиевое } \\
\text { кольцо на киёп- } \\
\text { ках синее с } \\
\text { Авойным белым } \\
\text { кодом } \\
\text { Aluminum } \\
\text { rivet ring blue } \\
\text { coloured with } \\
\text { double white } \\
\text { code }\end{array}$ & & $\begin{array}{l}\text { Метамическое } \\
\text { кольцо РЦК или } \\
\text { аяюминиевое } \\
\text { кольцо RRRCN } \\
\text { на киёпках с } \\
\text { Авойным чёр- } \\
\text { ным кодом } \\
\text { Metal ring of } \\
\text { national ringing } \\
\text { center or alu- } \\
\text { minum rivet ring } \\
\text { of the RRRCN } \\
\text { with double } \\
\text { black code }\end{array}$ & \\
\hline $\begin{array}{l}\text { Россия } \\
\text { Russia }\end{array}$ & $\begin{array}{l}\text { Архангельская область } \\
\text { Arkhangelsk district }\end{array}$ & $\begin{array}{l}\text { Все виды хищ- } \\
\text { ных птиц, кроме } \\
\text { скопы } \\
\text { All raptors, ex- } \\
\text { cept the Osprey }\end{array}$ & $\begin{array}{l}\text { Алюминие- } \\
\text { вое кольцо на } \\
\text { кёпках чёрное } \\
\text { снизу и сере- } \\
\text { бристое сверху } \\
\text { с } А \text { войным } \\
\text { чёрным кодом } \\
\text { на серебристом } \\
\text { фоне и белым } \\
\text { кодом на чёр- } \\
\text { ном фоно } \\
\text { Aluminum rivet } \\
\text { ring silver-over- } \\
\text { black coloured } \\
\text { with double } \\
\text { black/white code }\end{array}$ & & $\begin{array}{l}\text { Метамиическое } \\
\text { кольцо РЦК или } \\
\text { алюминиевое } \\
\text { кольцо на киёп- } \\
\text { ках с Авойным } \\
\text { чёрным кодом } \\
\text { RRRCN } \\
\text { Metal ring of } \\
\text { national ring- } \\
\text { ing center or } \\
\text { aluminum rivet } \\
\text { ring with double } \\
\text { black code of } \\
\text { RRRCN }\end{array}$ & \\
\hline $\begin{array}{l}\text { Россия } \\
\text { Russia }\end{array}$ & п-ов Ямам / Yamal peninsula & $\begin{array}{l}\text { Bсе виды хиш- } \\
\text { ных птиц } \\
\text { All raptors }\end{array}$ & $\begin{array}{l}\text { Пластиковое } \\
\text { бело-красное } \\
\text { кольцо } \\
\text { Plastic white- } \\
\text { orange ring }\end{array}$ & & $\begin{array}{l}\text { Метамиическое } \\
\text { кольцо РЦК } \\
\text { Metal ring of } \\
\text { national ringing } \\
\text { center }\end{array}$ & \\
\hline $\begin{array}{l}\text { Россия } \\
\text { Russia }\end{array}$ & $\begin{array}{l}\text { Волго-Ураиьский (Нижегород- } \\
\text { ская, Кировская, Пензенская, } \\
\text { Ульяновская, Самарская, } \\
\text { Оренбургская области, Респу- } \\
\text { блики Чувашская, Мордов- } \\
\text { ская, Марийская, УАмуртская, } \\
\text { Татарстан, Башкортостан и } \\
\text { Пермский край) } \\
\text { Volga-Ural (N. Novgorod, Ki- } \\
\text { rov, Penza, Ulyanovsk, Samara, } \\
\text { Orenburg districts, Chuvash- } \\
\text { skaya, Mordovskaya, Mari-El, } \\
\text { Udmurtskaya, Tatarstan, } \\
\text { Bashkortostan Republics and } \\
\text { Permskiy Kray) }\end{array}$ & $\begin{array}{l}\text { Все виды хиш- } \\
\text { ных птиц, кроме } \\
\text { большого подор- } \\
\text { лика и орлана- } \\
\text { белохвоста } \\
\text { All raptors, ex- } \\
\text { cept the Greater } \\
\text { Spotted Eagle } \\
\text { and White-Tailed } \\
\text { Eagle }\end{array}$ & $\begin{array}{l}\text { Пластиковое } \\
\text { бело-зеленое } \\
\text { кольцо или } \\
\text { алюминиевое } \\
\text { кольцо на клёп- } \\
\text { ках зелёное } \\
\text { снизу и сере- } \\
\text { бристое сверху } \\
\text { с двойным } \\
\text { чёрным кодом } \\
\text { Plastic white- } \\
\text { green ring or } \\
\text { aluminum rivet } \\
\text { ring silver-over- } \\
\text { green coloured } \\
\text { with double } \\
\text { black code }\end{array}$ & & $\begin{array}{l}\text { Метамиическое } \\
\text { кольцо РЦК или } \\
\text { алюминиевое } \\
\text { кольцо RRRСN } \\
\text { на киёпках с } \\
\text { Авойным чёр- } \\
\text { ным кодом } \\
\text { Metal ring } \\
\text { of national } \\
\text { ringing center } \\
\text { or aluminum } \\
\text { rivet ring of the } \\
\text { RRRCN with } \\
\text { double black } \\
\text { code }\end{array}$ & \\
\hline
\end{tabular}




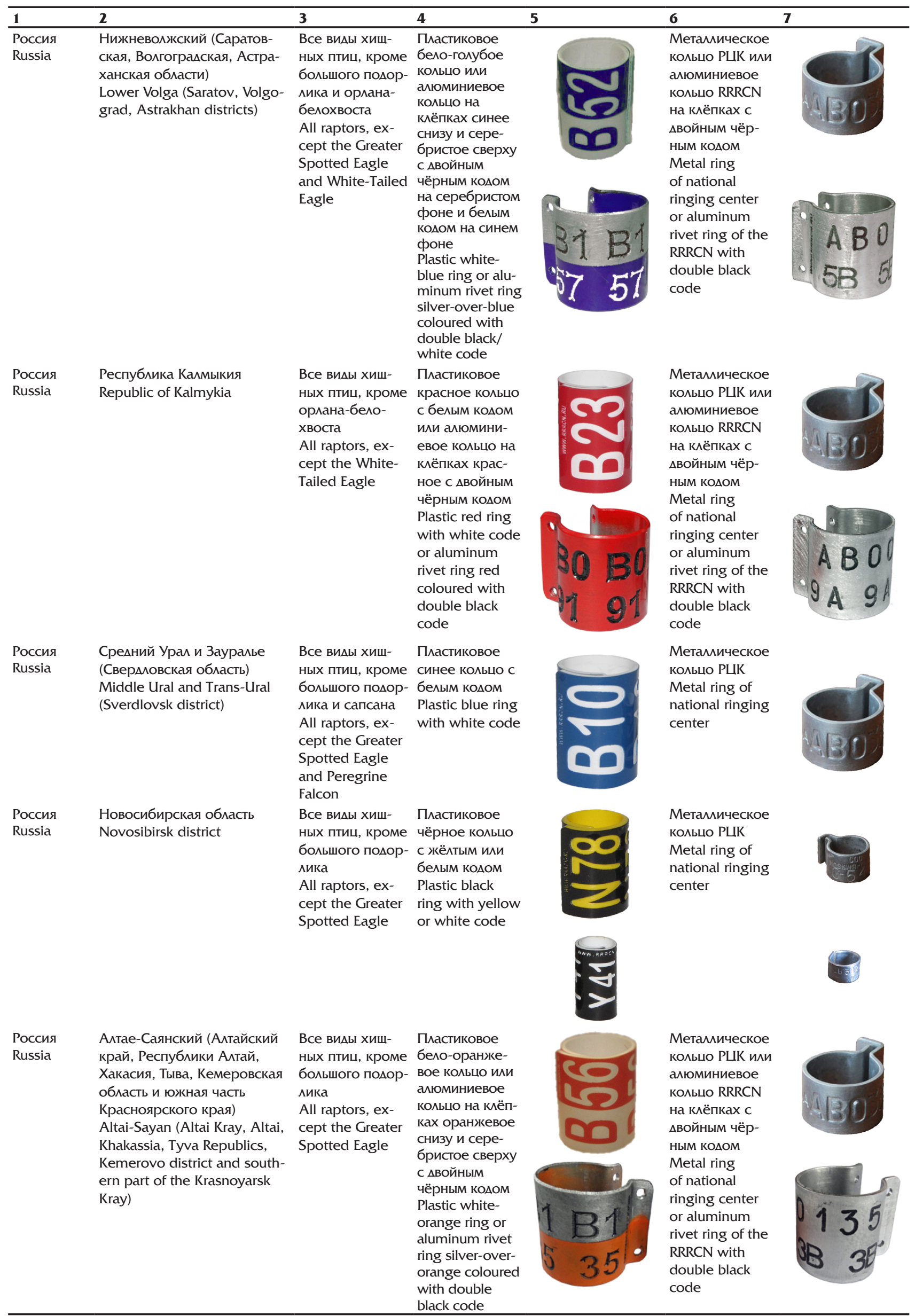




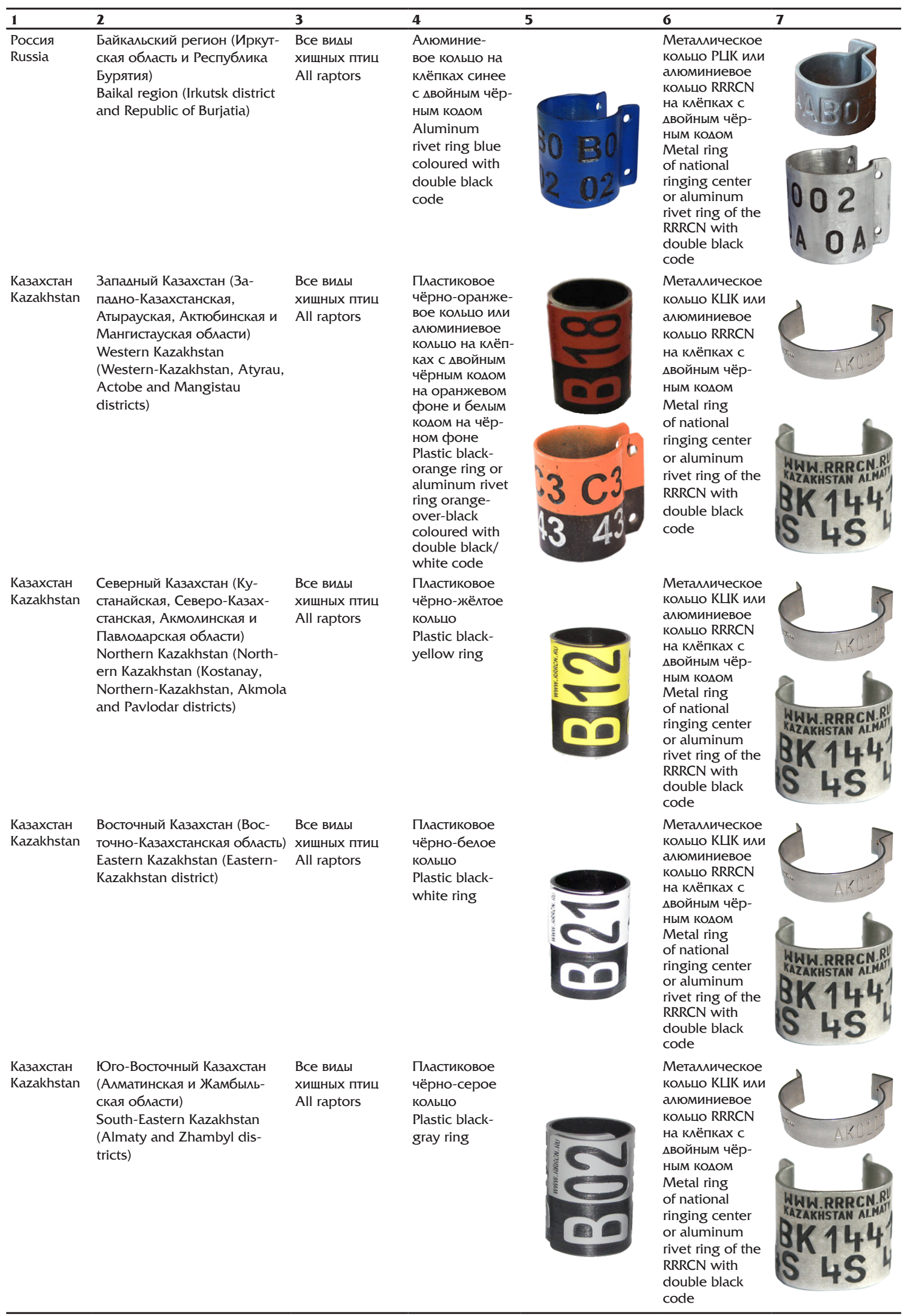




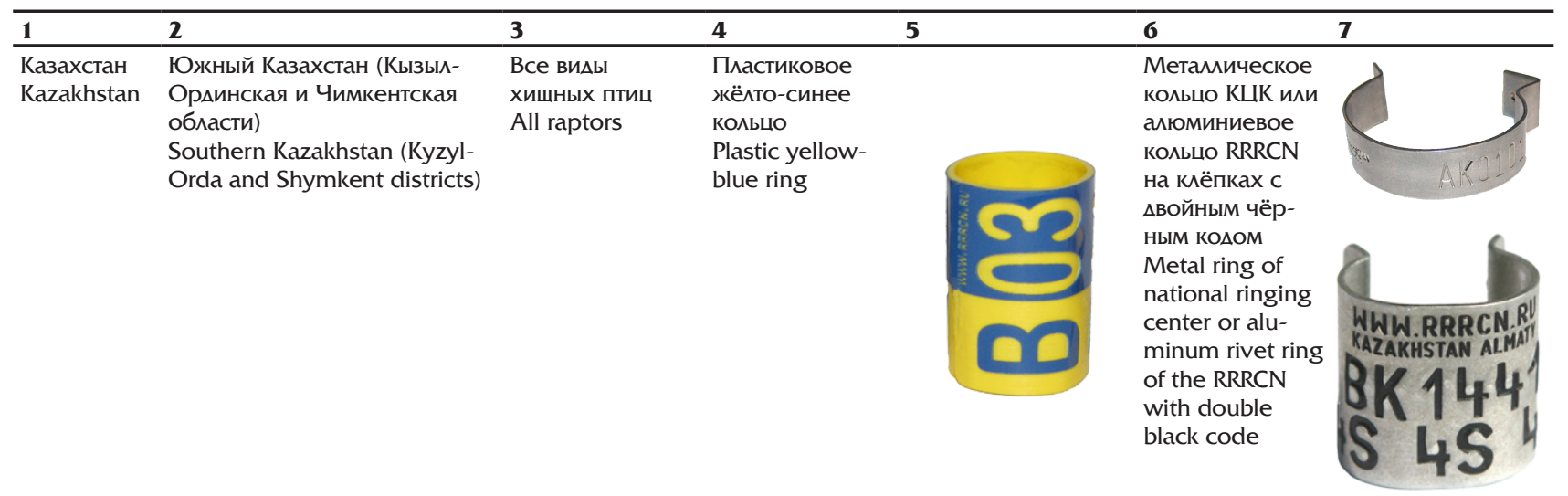

\begin{tabular}{|c|c|c|c|}
\hline \multicolumn{4}{|c|}{ Повидовые схемы кольцевания / Ringing sch } \\
\hline $\begin{array}{l}\text { Россия } \\
\text { Russia }\end{array}$ & $\begin{array}{l}\text { Северо-Запал } \\
\text { (Ленинградская, Псковская, } \\
\text { Новгородская, Тверская } \\
\text { области) } \\
\text { North-West of Russia (Lenin- } \\
\text { grad, Pskov, Nodgorod and } \\
\text { Tver districts) }\end{array}$ & $\begin{array}{l}\text { Скопа (Pandion } \\
\text { haliaetus) } \\
\text { Osprey (Pandion } \\
\text { haliaetus) }\end{array}$ & $\begin{array}{l}\text { Пластиковое } \\
\text { красное кольцо } \\
\text { с белым колом } \\
\text { Plastic red ring } \\
\text { with white code }\end{array}$ \\
\hline $\begin{array}{l}\text { Россия } \\
\text { Russia }\end{array}$ & $\begin{array}{l}\text { Карелия (Республика } \\
\text { Kaрелия) } \\
\text { Karelia (Republic of Karelia) }\end{array}$ & $\begin{array}{l}\text { Скопа (Pandion } \\
\text { haliaetus) } \\
\text { Osprey (Pandion } \\
\text { haliaetus) }\end{array}$ & $\begin{array}{l}\text { Пластиковое } \\
\text { синее кольцо с } \\
\text { белым кодом } \\
\text { Plastic blue ring } \\
\text { with white code }\end{array}$ \\
\hline
\end{tabular}

Россия

Russia

Pocсия

Россия

Russia

Россия Russia haliaetus)
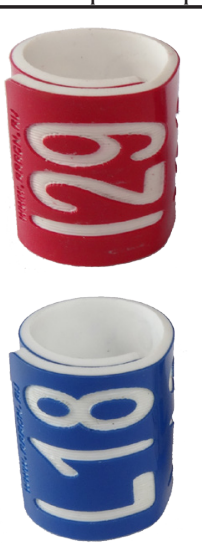

Пластиковое красное кольцо с белым коАОм Plastic red ring with white code
Верхняя Волга (Ярославская, Вологодская, Костромская области)

Upper Volga (Yaroslavl, Vologda and Kostroma districts)

Скопа (Pandion haliaetus)

Osprey (Pandion

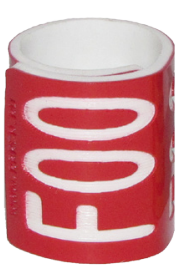

Орлан-белохвост Алюминиевое (Haliaeetus кольцо на albicilla) киёпках

White-Tailed чёрного цвета с Eagle (Haliaeetus Авойным белым albicilla) кОАОм

North-West of Russia (Leningrad, Pskov, Nodgorod and Tver districts)

Верхняя Волга (Ярославская, Вологодская, Костромская область)

Upper Volga (Yaroslavl, Vologda, Kostroma districts)

Aluminum rivet ring black colour with double white code

Орлан-белохвост Алюминиевое (Haliaeetus кольцо на albicilla) клёпках c White-Tailed $\quad$ ввойным Eagle (Haliaeetus чёрным кодом albicilla) Aluminum rivet ring with double black code

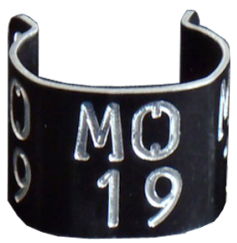

Алюминиевое Авухцветное кольцо чёрное сверху и серебристое снизу Aluminum black-over-silver rivet ring

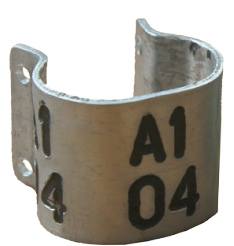

Алюминиевое Авухцветное кольцо серебристое сверху и зелёное снизу Aluminum silver-overgreen rivet ring Алюминиевое Авухцветное кольцо

Орлан-белохвост Алюминиевое $\begin{array}{ll}\text { albicilla) } & \text { кольцо наёпках }\end{array}$ White-Tailed чёрного цвета c
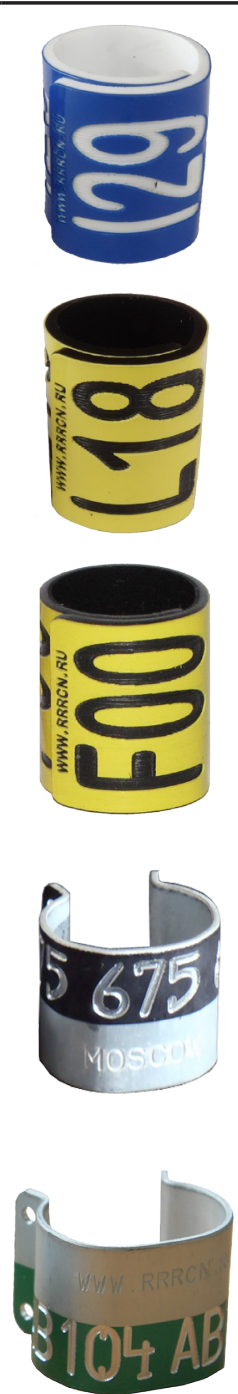
Татарстан, УАмуртская, Марий-Эл, Чувашия, Мордовия и южная часть Пермского края)

Middle Volga (Ulyanovsk, Samara, N. Novgorod districts, Tatarstan, Udmurtskaya, Mari-El, Chuvashskaya, Mordovskaya Republics and southern part of the Perms kiy Kray)
Eagle (Haliaeetus Авойным белым albicilla) КОАОМ

Aluminum rivet ring black colour with double white code серебристое сверху и зелёное снизу Aluminum silver-overgreen rivet ring
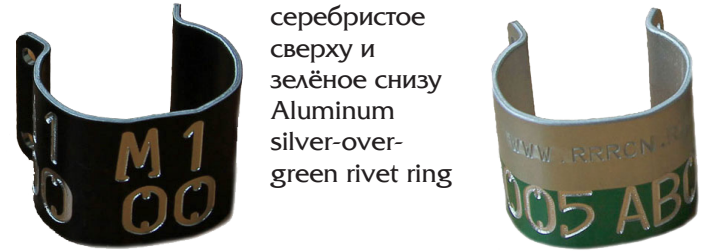


\begin{tabular}{|c|c|c|c|c|c|}
\hline 1 & 2 & 3 & 4 & 6 & 7 \\
\hline $\begin{array}{l}\text { Россия } \\
\text { Russia }\end{array}$ & $\begin{array}{l}\text { Запал Европейской части } \\
\text { России (Ленингралская, } \\
\text { Псковская, Новгородская, } \\
\text { Тверская, Ярославская, } \\
\text { Вологодская, Костромская, } \\
\text { Ивановская, Влацимирская, } \\
\text { Московская, Смоленская, } \\
\text { Брянская, Калужская, } \\
\text { Тульская, Рязанская, } \\
\text { Тамбовская, Аипецкая, } \\
\text { Орловская, Курская, } \\
\text { Воронежская, Белгородская } \\
\text { области) } \\
\text { Western of the European part } \\
\text { of Russia (Leningrad, Pskov, } \\
\text { Novgorod, Tver, Yaroslavl, } \\
\text { Vologda, Kostroma, Ivanovo, } \\
\text { Vladimir, Moscow, Smolensk, } \\
\text { Bryansk, Kaluga, Tula, Ryazan, } \\
\text { Tambov, Lipetsk, Orel, Kursk, } \\
\text { Voronezh, Belgorod districts) }\end{array}$ & $\begin{array}{l}\text { Большой } \\
\text { подорлик (Aquila } \\
\text { clanga) } \\
\text { Greater Spotted } \\
\text { Eagle (Aquila } \\
\text { clanga) }\end{array}$ & $\begin{array}{l}\text { П^астиковое } \\
\text { жёлто-синее } \\
\text { кольцо } \\
\text { Plastic yellow- } \\
\text { blue ring }\end{array}$ & $\begin{array}{l}\text { Метамическое } \\
\text { кольцо РЦК или } \\
\text { алюминиевое } \\
\text { кольцо RRRСN } \\
\text { на киёпках } \\
\text { с Авойным } \\
\text { чёрным кодом } \\
\text { Metal ring of } \\
\text { national ringing } \\
\text { center or alu- } \\
\text { minum rivet ring } \\
\text { of the RRRCN } \\
\text { with double } \\
\text { black code }\end{array}$ & \\
\hline $\begin{array}{l}\text { Россия } \\
\text { Russia }\end{array}$ & $\begin{array}{l}\text { Волго-Уральский } \\
\text { (Нижегородская, Кировская, } \\
\text { Пензенская, Ульяновская, } \\
\text { Самарская, Саратовская, } \\
\text { Оренбургская, ВолгограАская } \\
\text { и Астраханская области, } \\
\text { Республики Чувашия, } \\
\text { Мордовия, Марий-Э^, } \\
\text { Удмуртия, Татарстан, } \\
\text { Башкортостан и Пермский } \\
\text { край) } \\
\text { Volga-Ural (N. Novgorod, } \\
\text { Kirov, Penza, Ulyanovsk, } \\
\text { Samara, Orenburg, Volgograd, } \\
\text { Astrakhan districts, Chuvash- } \\
\text { skaya, Mordovskaya, Mari-El, } \\
\text { Udmurtskaya, Tatarstan, } \\
\text { Bashkortostan Republics and } \\
\text { Permskiy Kray) }\end{array}$ & $\begin{array}{l}\text { Большой } \\
\text { подорлик (Aquila } \\
\text { clanga) } \\
\text { Greater Spotted } \\
\text { Eagle (Aquila } \\
\text { clanga) }\end{array}$ & $\begin{array}{l}\text { П^астиковое } \\
\text { жёлтое кольцо с } \\
\text { чёрным кодом } \\
\text { Plastic yellow } \\
\text { ring with black } \\
\text { code }\end{array}$ & $\begin{array}{l}\text { Метамическое } \\
\text { кольцо РЦК или } \\
\text { алюминиевое } \\
\text { кольцо RRRСN } \\
\text { на киёпках } \\
\text { с Авойным } \\
\text { чёрным кодом } \\
\text { Metal ring of } \\
\text { national ringing } \\
\text { center or alu- } \\
\text { minum rivet ring } \\
\text { of the RRRCN } \\
\text { with double } \\
\text { black code }\end{array}$ & \\
\hline $\begin{array}{l}\text { Россия } \\
\text { Russia }\end{array}$ & $\begin{array}{l}\text { Запалная Сибирь } \\
\text { (Челябинская, Свердловская, } \\
\text { Курганская, Тюменская, } \\
\text { Омская, Томская, } \\
\text { Новосибирская области и } \\
\text { Алтайский край) } \\
\text { Western Siberia (Chelyabinsk, } \\
\text { Sverdlovsk, Kurgan, Tumen, } \\
\text { Omsk, Tomsk, Novosibirsk } \\
\text { districts and Altai Kray) }\end{array}$ & $\begin{array}{l}\text { Большой } \\
\text { подорлик (Aquila } \\
\text { clanga) } \\
\text { Greater Spotted } \\
\text { Eagle (Aquila } \\
\text { clanga) }\end{array}$ & $\begin{array}{l}\text { Пластиковое } \\
\text { чёрное кольцо } \\
\text { с жёлтым кодом } \\
\text { Plastic black } \\
\text { ring with yellow } \\
\text { code }\end{array}$ & $\begin{array}{l}\text { Метамическое } \\
\text { кольцо РЦК или } \\
\text { алюминиевое } \\
\text { кольцо RRRСN } \\
\text { на киёпках } \\
\text { с Авойным } \\
\text { чёрным кодом } \\
\text { Metal ring of } \\
\text { national ringing } \\
\text { center or alu- } \\
\text { minum rivet ring } \\
\text { of the RRRCN } \\
\text { with double } \\
\text { black code }\end{array}$ & \\
\hline $\begin{array}{l}\text { Россия } \\
\text { Russia }\end{array}$ & $\begin{array}{l}\text { Южный Урал (Республика } \\
\text { Башкортостан и Челябинская } \\
\text { область) } \\
\text { Southern Ural (Republic od } \\
\text { Bashkortostan and Chely- } \\
\text { abinsk districts) }\end{array}$ & $\begin{array}{l}\text { Cапсан (Falco } \\
\text { peregrinus) } \\
\text { Peregrine Falcon } \\
\text { (Falco peregri- } \\
\text { nus) }\end{array}$ & $\begin{array}{l}\text { Пластиковое } \\
\text { бело-зеленое } \\
\text { кольцо } \\
\text { Plastic white- } \\
\text { green ring }\end{array}$ & $\begin{array}{l}\text { Пластиковое } \\
\text { красное кольцо } \\
\text { с белым кодом } \\
\text { Plastic red ring } \\
\text { with white code }\end{array}$ & \\
\hline $\begin{array}{l}\text { Россия } \\
\text { Russia }\end{array}$ & $\begin{array}{l}\text { Средний Урал (Пермская, } \\
\text { Сверцмовская области) } \\
\text { Middle Ural (Perm and Sverd- } \\
\text { lovsk districts) }\end{array}$ & $\begin{array}{l}\text { Cancaн (Falco } \\
\text { peregrinus) } \\
\text { Peregrine Falcon } \\
\text { (Falco peregri- } \\
\text { nus) }\end{array}$ & $\begin{array}{l}\text { Пластиковое } \\
\text { синее кольцо с } \\
\text { белым кодом } \\
\text { Plastic blue ring } \\
\text { with white code }\end{array}$ & $\begin{array}{l}\text { Пластиковое } \\
\text { красное кольцо } \\
\text { с белым кодом } \\
\text { Plastic red ring } \\
\text { with white code }\end{array}$ & \\
\hline
\end{tabular}

Казахстан), с 2014 г. разработаны ешё 8 схем цветного мечения хишных птиц мля 7 регионов России (Северо-Запац России, Карелия, Архангельская область, Калмыкия, Средний Урах и Зауралье, Новосибирская область, Байкаиьский регион) и 1
Eagle are expanded on some regions: for ringing Greater Spotted Eagle on the West of the European part of Russia the color scheme was developed, for ringing Osprey in Karelia and the Northwest of Russia (table 2) the color schemes were developed. 


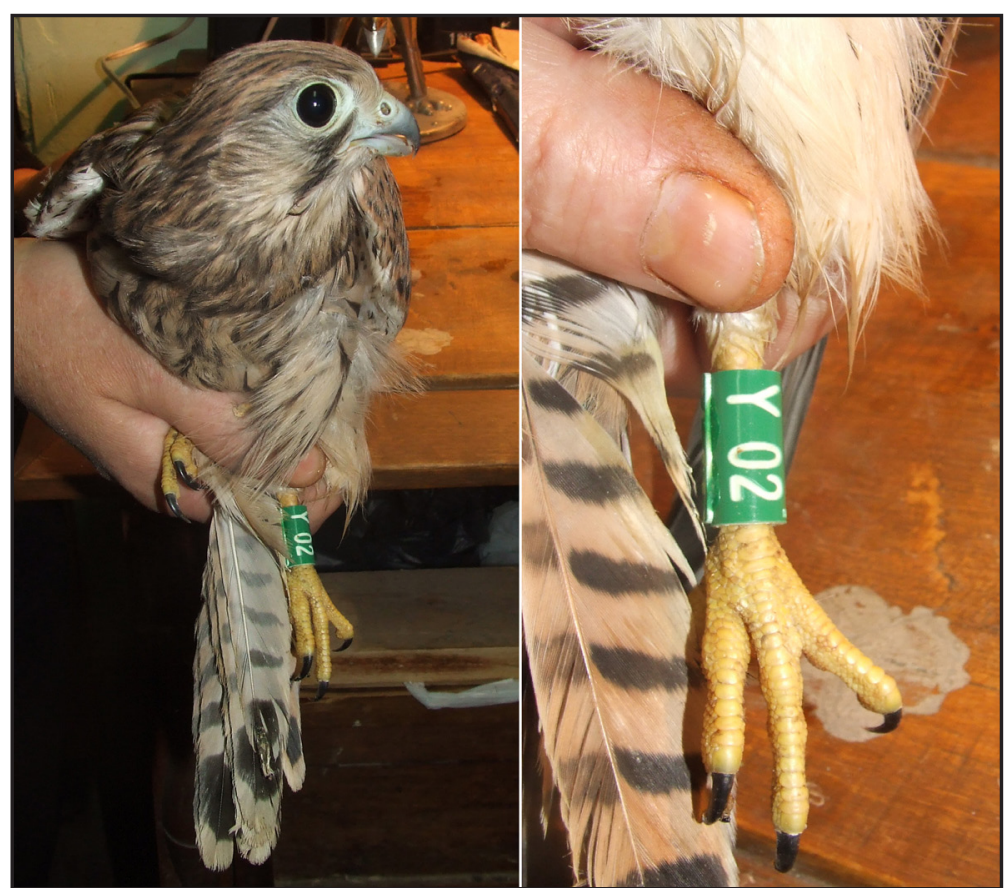

- мля Казахстана (Южный Казахстан) (табл. 2, рис. 2). Также расширены на несколько регионов схемы цветного мечения скопы и большого подорлика: мля мечения большого подорлика разработана цветовая схема на запац Европейской части России, мля мечения скопы разработаны цветовые схемы на Карелию и Северо-Запац России (табл. 2).

Отдельная цветная схема мечения хищных птиц разработана мия Симбирского центра спасения хищных птиц (рук. Г. Пилюгина и О. Аанилова) - пластиковое кольцо, зелёное с белым кодом, одевается на левую ^апу птицы (рис. 3). Такими кольцами метятся птицы, выпускаемые в дикую природу после реабилитации в Ульяновской области. Схема походит на таковую в Болгарии, от которой отличается отсутствием алюминиевого кольца на второй лапе.

\section{Результаты кольцевания}

В 2014 г. в программе цветного мечения хишных птиц участвовами 39 орнитологов-исследователей и мюбителей птиц, которые в обшей сложности окольцевали 889 особей 23 видов соколообразных и сов (табл. 3) в 2-х областях Казахстана (Алматинская и Восточно-Казахстанская области) и 15 субъектах Российской Фемерации (Волгогралская, Самарская, Ульяновская, Нижегородская, Ярославская, Вологодская, Псковская, Сверциовская, Новосибирская области, республики Татарстан, Мордовия, Алтай, Тыва, Хакасия и Аитайский край).

Из меченых птиц мидируют курганник
Рис. 3. Пустельга (Falco tinnunculus), помеченная цветным кольцом Симбирского центра спасения хищных птиц Аля выпуска птицы в УАьяновской обмасти. Фото Г. Пилюгиной.

Fig. 3. Kestrel (Falco tinnunculus) with color ring from Simbirsk Raptor Rescue Center for release this bird in the Ulyanovsk region. Photo by G. Pilugina.

The separate color ringing scheme for raptors was developed for the Simbirsk Rescue Center of Raptors (dir. G. Piljugina and O. Danilova) - the plastic ring, green with a white code, to be put on the left leg of a bird (fig. 3). The birds which are let out to the wild nature after rehabilitation in the Ulyanovsk region are marked with such rings. The scheme resembles that in Bulgaria from which differs by an absence of an aluminum ring on the second leg.

\section{Results of ringing}

In 2014 in the program of color ringing of raptors 39 ornithologists-researchers and birdwatchers were participating, who in total have ringed 889 individuals of 23 species of birds of prey and owls (table 3 ) in 2 regions of Kazakhstan (Almaty and East Kazakhstan region) and 15 subjects of the Russian Federation (Volgograd, Samara, Ulyanovsk, Nizhniy Novgorod, Yaroslavl, Vologda, Pskov, Sverdlovsk, Novosibirsk regions, republics of Tatarstan, Mordovia, Altai, Tyva, Khakassia and Altai).

From ringed birds the leaders are Upland Buzzard (Buteo hemilasius) - 154 individuals, Imperial Eagle (Aquila heliaca) - 110 individuals, Steppe Eagle (Aquila nipalensis) - 95 individuals, Long-Legged Buzzard (Buteo rufinus) - 87 individuals, White-Tailed Eagle (Haliaeetus albicilla) - 78 individuals (table 3 ).

Ringing was carried out by several groups. The biggest quantity of birds (more than 400 individuals) were ringed in the AltaiSayan region by the groups under the direction of I. Karyakin (participants E. Nikolenko, E. Schnayder, E. Yemelyanova, A. Karpov, A. Vagin, M. Horvath, T. Juhasz, M. Prommer) and S. Vazhov and R. Bachtin. In the Volgograd region V. Pimenov and M. Bajbakov ringed 121 raptors, mainly Steppe Eagles and Long-Legged Buzzards. R. Bekmansurov in Tatarstan ringed 139 raptors, mainly Imperial Eagles and White-Tailed Eagles. M. Babushkin and O. Dyomina in Vologda and Yaroslavl regions ringed 64 individuals of Ospreys and White-Tailed Eagles. Also ringers worked in Northwest of Russia - V. Pchelintsev, M. Shashkin, U. Selis, U. Vali, G. Sein, 
Табл. 3. Сводка по мечению птиц в 2014 г.

Table 3. Short report about the birds ringing in 2014.

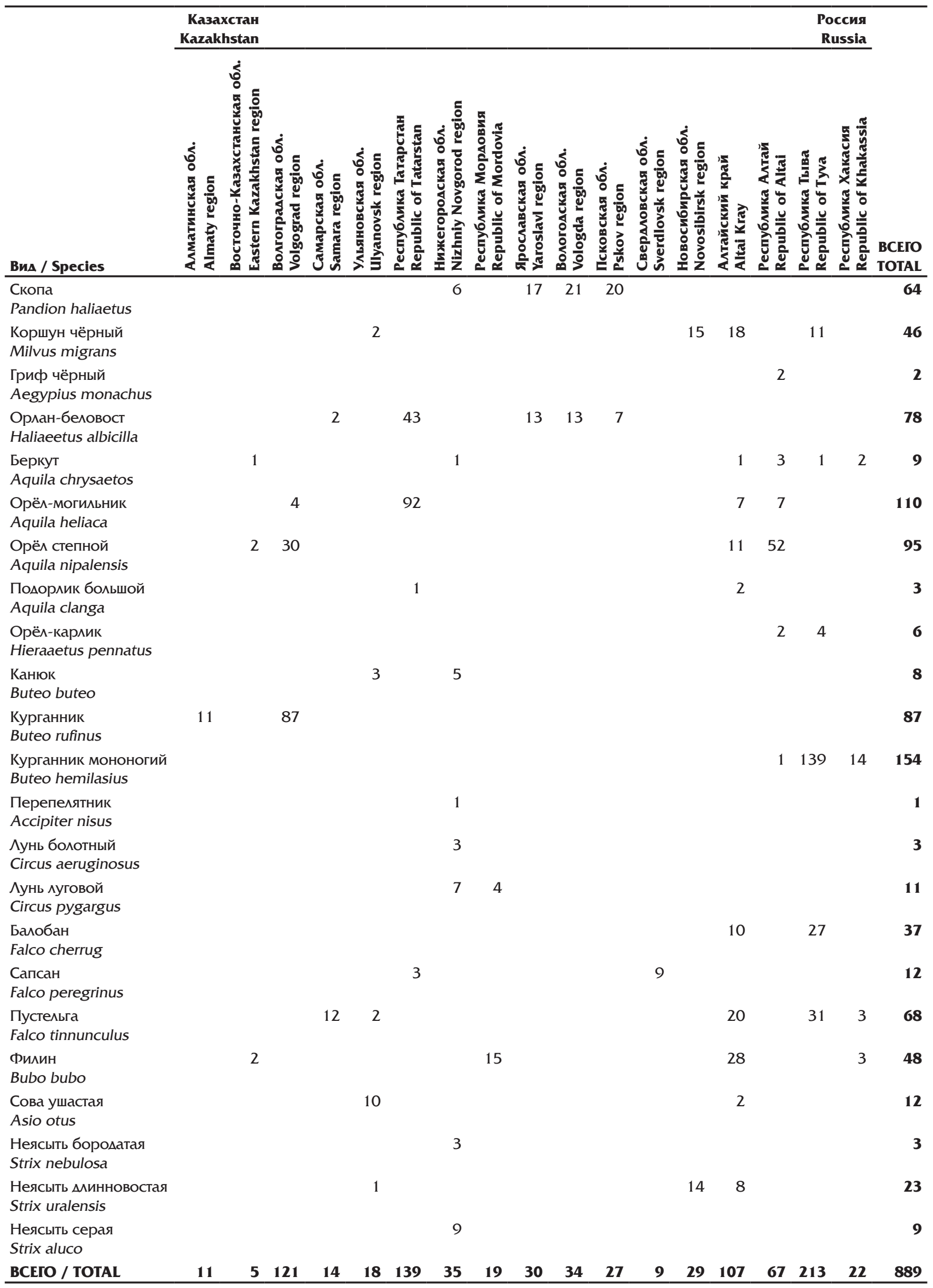


мохноногий (Buteo hemilasius) - 154 особи, орёл-могильник (Aquila heliaca) - 110 особей, орёл степной (Aquila nipalensis) 95 особей, курганник (Buteo rufinus) - 87 особей, орлан-белохвост (Haliaeetus albicilla) - 78 особей (табл. 3).

Кольцевание осушествлялось несколькими группами. Наибольшее количество птиц (более 400 особей) было окольцовано в Алтае-Саянском регионе группами под руководством И. Карякина (участники Э. Николенко, Е. Шнайдер, Е. Емельянова, А. Карпов, А. Вагин, М. Horvath, T. Juhasz, M. Prommer) и С. Важова и P. Бахтина. В Волгоградской области В. Пименовым и М. Байбаковым был окольцован 121 хишник, преимушественно степные орлы и курганники. Р. Бекмансуров в Татарстане окольцевал 139 хишников, преимушественно орлов-могильников и орланов-белохвостов. М. Бабушкин и О. $\triangle$ ёмина в Вологодской и Ярославской областях окольцевали 64 особи скоп и орланов-белохвостов. Также кольцеватели работали на Северо-Запаце России - В. Пчелинцев, М. Шашкин, U, Selis, U. Vali, G. Sein, в Нижегородской области - A. Аевашкин, И. Гучев, А. Москалик, С. Елисеев, Н. Колесова, О. Чернышев, в МорАовии - С. Спиридонов, Самарской области - О. Смагина, в СверАмовской области - А. Хиопотова и М. Шершнёв, в Новосибирской области - $\Delta$. Штоль, А. Томиленко и А. Милежик, в Восточном и ЮгоВосточном Казахстане - А. Барашкова и И. Смелянский.

\section{Возвраты}

За 2014 г. и первые 5 месяцев 2015 г. получена инсормация о регистрации 52 птиц с кольцами, из которых 41 удалось идентисрицировать (табл. 4): 40 - возвраты наших птиц, 1 возврат - зарубежная птица в России.

\section{Возврать наших птиц}

\section{1. Скопа (Pandion haliaetus)}

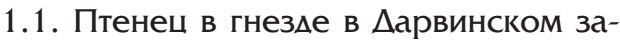
поведнике (Россия) был помечен цветными кольцами E-05 26 июля 2014 г. Мирославом Бабушкиным ${ }^{32}$; найден мёртвым (Аобыт пернатым хишником, по всей виАимости филином Bubo bubo) 5 августа 2014 г. около гнезАа ${ }^{33}$ : Аистанция - 0 км, азимут - 0 градусов, продолжительность -11 нней. in the Nizhniy Novgorod region - A. Levashkin, I. Guchev, L. Moskalik, S. Yeliseyev, N. Kolesova, O. Tchernyshev, in Mordovia - S. Spiridonov, in the Samara region - O. Smagina, in the Sverdlovsk region - A. Hlopotova and $M$. Shershnyov, in the Novosibirsk region - D. Shtol, A. Tomilenko and A. Milezhik, in East and Southeast Kazakhstan - A. Barashkova and I. Smelyansky.

\section{Returns}

For 2014 and the first 5 months of 2015 the information on registration of 50 birds with rings is received from which it was possible to identify 40 (tab. 4): 39 - recoveries of our birds, 1 recovery - a foreign bird in Russia.

\section{Discussion}

Among recoveries the Imperial Eagle (14 individuals) and the White-Tailed Eagle (9 individuals) are the leaders. And unfortunately among recoveries of the Imperial Eagle basically these are the birds which were lost on power lines on breeding territories, or injured on power lines and extracted by poachers on migrations. Among recoveries of the White-Tailed Eagle fortunately 7 are live birds on winterings and only two - dead (one - in Donetsk region of the Ukraine, another - in the Samara region in Russia).

One of the dead White-Tailed Eagle was found in national Park "Samarskaya Luka" in a suburb of a city of Zhigulevsk, ornithologists of the Samara branch of the Russian Birds Conservation Union and employees of the National Park were informed about its finding, but the corpse of a White-Tailed Eagle remained on the ground, absolutely unnecessary for the ornithologists and the nature protection organizations of Samara region though different local residents and visitors of the national park regularly informed about it. As a result the corpse had decayed, having carried away with itself the information on causes of death of a bird. Though some respondents informed that the bird had been shot, this fact remained unconfirmed.

The recoveries received in a course of ringing the White-Tailed Eagles on Middle Volga, show a southwest direction of migration - all both distant returns from the Ukraine, and near returns from Penza and Ulyanovsk regions, confirm a general southwest direction of migration of young birds. The most part of supervision of ringed White-Tailed

32 http://demo.nextgis.ru/birdreport/report/2992

33 http://demo.nextgis.ru/birdreport/report/3777 
Табл. 4. Сводка о сиучаях встреч и находок окольцованных птиц в 2014 - первой половине 2015 гг.

Table 4. Brief information about birds from which the returns were received in 2014 - first half of 2015

Возвраты птиц, окольцованных по программе RRRCN / The recoveries of birds ringed in the RRRCN programme Вим / Species
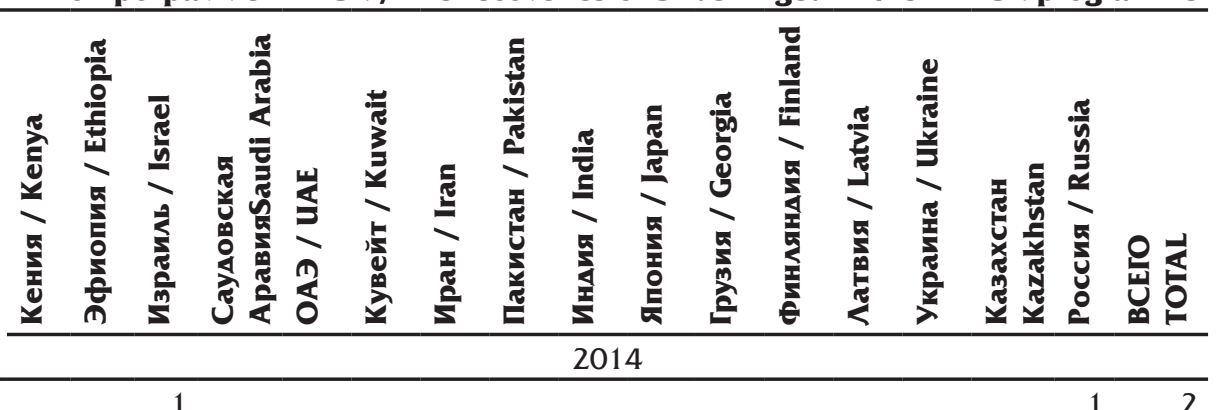

Скопа

Pandion haliaetus

Орлан белоплечий

Haliaeetus pelagicus

Орлан-белохвост

Haliaeetus albicilla

Орёл-могильник

Aquila heliaca

Орёл степной

Aquila nipalensis

Курганник

Buteo rufinus

Балобан

Falco cherrug

Филин

Bubo bubo

Bcero зa 2014 ros /

Total for 2014

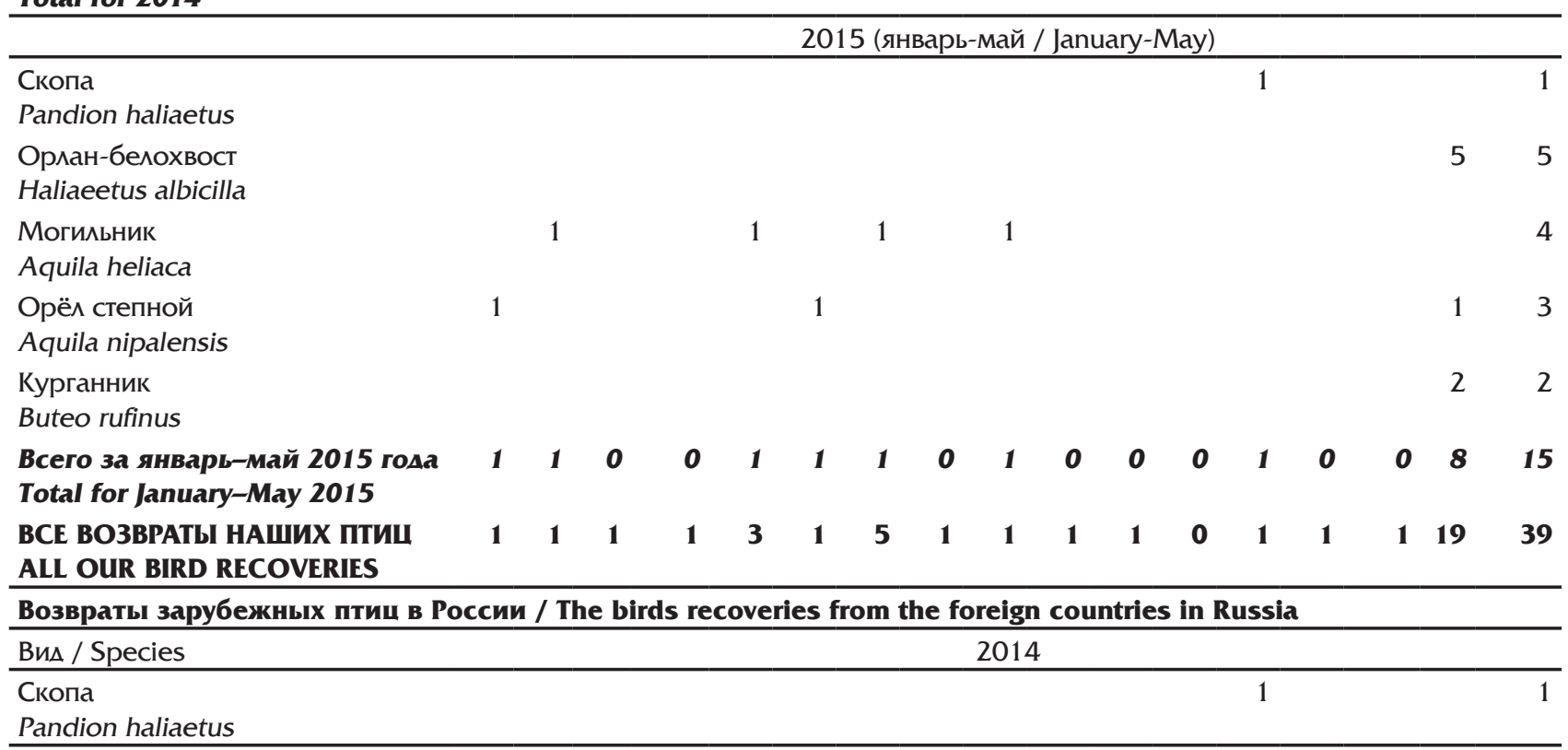

1.2. Птенец в гнезде в Аарвинском заповеднике (Россия) был помечен цветными кольцами F-79 10 июля 2014 г. Мирославом Бабушкиным ${ }^{34}$; ссротограсрирован Аави Аило (Lavi Lilo) 22 октября 2014 г. на рыбоводческих прудах близ с. Маоз Хаим
Eagles is received from a place of wintering of these birds near Novouljanovsk of the Ulyanovsk region (Russia). Considering the absence of repeated supervision on a winter congestion of the same ringed birds, it is possible to assume that during the win-

34 http://demo.nextgis.ru/birdreport/report/2935 


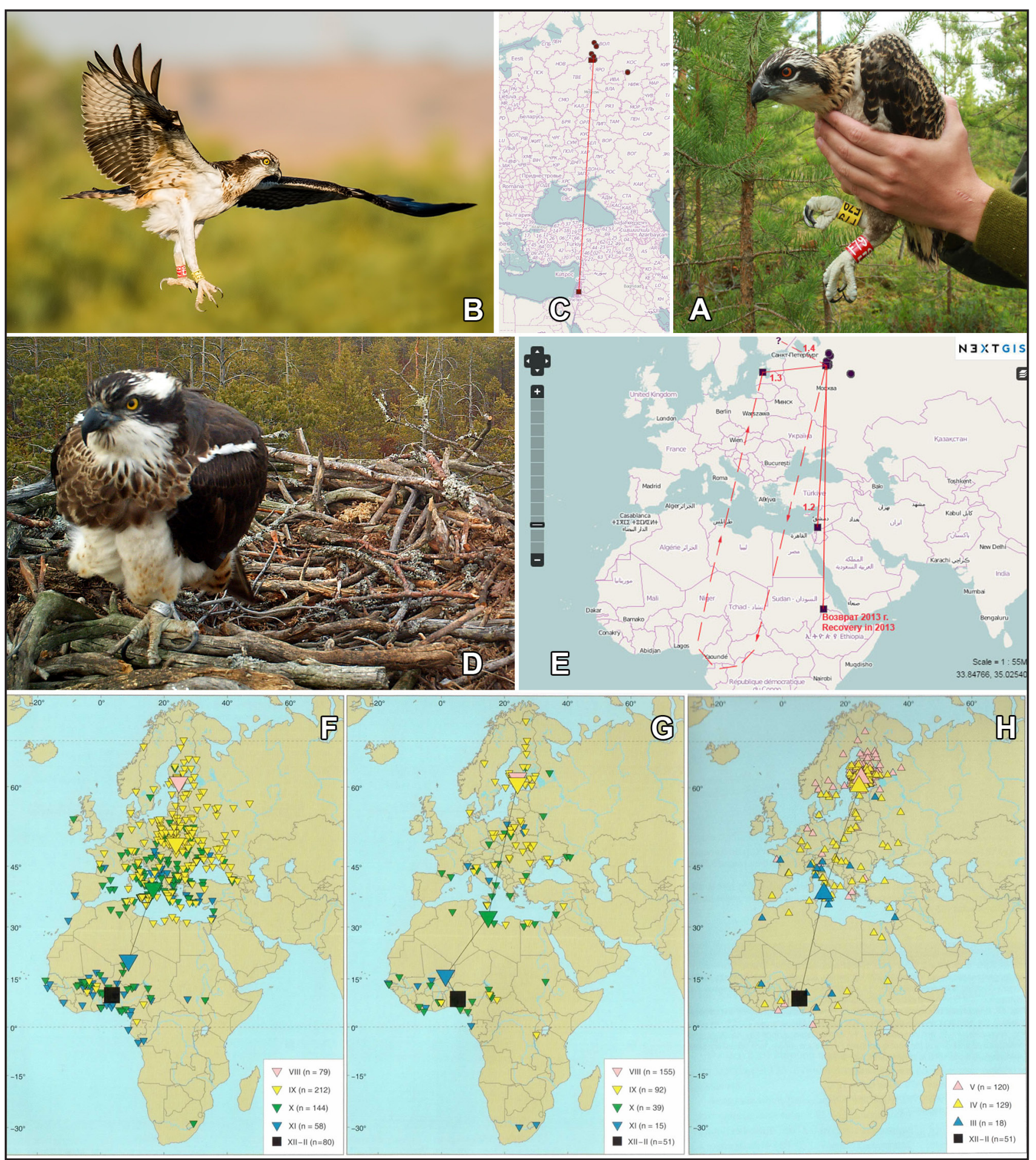

Pис. 4. Скопа (Pandion haliaetus), помеченная кольцами F-79 в Аарвинском заповеднике (Россия) в 2014 г. - А (фото М. Бабушкина), она же на своей первой осенней миграции в Израиле в октябре 2014 г. - В (фото А. Аило), схема возврата этой скопы - С; скопа с финским кольцом, снятая фотоловушкой в Аарвинском заповеднике - D (фото М. Бабушкина), схемы возвратов от скоп, помеченных в рамках программы цветного мечения хишных птиц Российской сети изучения и охраны пернатых хищников в 2012-2014 гг. - E; возвраты от скоп, окольцованных в Финляндии (из Saurola et al., 2013): осенняя миграция скоп первого года жизни (1 ${ }^{\text {st }}$ sу) окольцованных птенцами $-F$, осенняя миграция взрослых скоп ( $>2^{\text {nd }}$ sу) окольцованных птенцами $-G$, весенняя миграция взрослых скоп $>3^{\text {rd }}$ sy) окольцованных птенцами - H (Ежемесячные средние позиции обозначены крупными символами, связанными минией, определяющей усредненный маршрут миграции).

Fig. 4. Osprey (Pandion haliaetus) with color rings F-79 in Darwin State Nature Biosphere Reserve (Russia) in 2014 r. - A (photo by M. Babushkin), again it on its first spring migration in Israel in October 2014- B (photo by L. Lilo), the recoveries scheme of this Osprey - C; Osprey with Finnish ring, shot by trail camera in Darvin State Nature Biosphere Reserve - D (photo by M. Babushkin), Schemes of recoveries of Osprey, ringed within the limits of the Raptor Color Ringing Program of the Russian Raptor Research and Conservation Network in 2012-2014 - E; recoveries of Osprey, ringed in Finland (from: Saurola et al., 2013): autumn migration of first-year ( $1^{\text {st }}$ sy) Ospreys ringed as nestlings $-F$, autumn migration of adult ( $>2^{\text {nd }}$ sy) Ospreys ringed as nestlings $-G$, spring migration of older $\left(>3^{\text {rd }}\right.$ sy) Ospreys ringed as nestlings $-H$ (Monthly median positions are indicated by large symbols connected with a line). 
(Maoz Hayim) в долине Бейт Шеан (Beit Shean) в Израиле ${ }^{35}$ : дистанция - 2935 км, азимут - 185 градусов, продолжительность - 105 Аней.

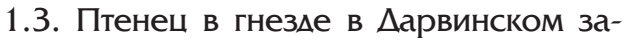
поведнике (Россия) был помечен цветными кольцами F-42 10 июля 2014 г. Мирославом Бабушкиным ${ }^{36}$; сфотограсрирован Алексеем Курочкиным 17 мая 2015 г. на побережье Балтийского моря в Аатвии ${ }^{37}$ : Аистанция - 883,5 км, азимут - 270,5 граАусов, продолжительность - 672 Аня (1 год и 10 месяцев).

2. Орлан-белохвост (Haliaeetus albicilla)

2.1. ОАин из трёх птенцов в гнезде близ с. Вырастайкино УАьяновской области (Россия) был помечен кольцами М-110 и AB-010 26 мая 2012 г. Ринуром Бекмансуровым $^{38}$; найлен мёртвым 22 февраяя 2014 г. на рыбхозе близ Славянска $\Delta$ онецкой области (Украина), сообшил Александр Макагон ${ }^{39}$ : Аистанция - 965,5 км, азимут - 240 грацусов, продолжительность - 638 нней (птица не Аожила всего 2,5 месяцев Ао 2-х лет).

2.2. ОАин из двух птенцов в гнезде на Саралинском участке Волжско-Камского государственного природного биосферного заповедника в Республике Татарстан (Россия) был помечен кольцом АВ-0066 28 мая 2011 г. Ринуром Бекмансуровым ${ }^{40}$; сфотограсрирован Михаилом Тимофеевым 2 февраля 2014 г. на зимовочном скоплении орланов близ г. Новоульяновска Ульяновской области (Россия) ${ }^{41}$ : Аистанция - 142 км, азимут - 207,5 градусов, продолжительность - 982 Аня (2 года 7 месяцев).

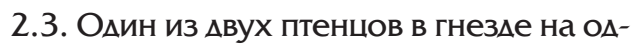
ном из островов р. Кама в Мамадышском районе Республики Татарстан (Россия) был помечен кольцами М-264 и АВ-264 20 июня 2013 г. Ринуром Бекмансуровым ${ }^{\mathbf{4 2}}$; сфотограсрирован Михаилом Тимосеевым 2 февраля 2014 г. на зимовочном скоплении орланов близ г. Новоульяновска УАьяновской области (Россия) $)^{43}$ : Аистанция - 257 км, азимут - 235 градусов, продолжительность - 228 Аней.

2.4. ОАин из двух птенцов в гнезде на ter period there is a constant movement of birds and only White-Tailed Eagles, are regularly replaced with others, by means of that single number of a congestion to hundred individuals is supported, but the real number of the birds passing through this point during winter movements can be 10 times bigger (Borodin et al., 2015; Pchelintsev, Shashkin, 2015).

Once again by the methods of ringing confirmed the area of wintering for Imperial Eagles of the Volga-Ural population in the countries of Arab peninsula and East Africa, revealed by B.-U. Meyburg (2015) by telemetry method. Migration assumed earlier to the Arabian winterings of some part of the Imperial Eagles breeding in the Russian part of Altai most part of which winter in Pakistan and India (fig. 6) is also confirmed. The proved fact of crossing on the Arabian winterings of Imperial Eagles from populations of Volga-Ural and Altai-Sayan regions can indirectly specify the exchange of genes between these populations, by means of interest of the Altai birds from wintering places to nesting places in the Volga-Ural region and on the contrary. The last point can be put in this question by molecular-genetic methods.

On the basis of two recoveries of rings from Iran of the Steppe Eagles from Altai belonging to east subspecies $A$. nipalensis nipalensis from breeding group of Southeast Altai, migration of individuals of these subspecies along the Afro-Euroasian migratory way to the area of wintering of the western subspecies of Steppe Eagle A. nipalensis orientalis is proved. This information allows to take a fresh look at the facts of nesting of large Steppe Eagles in mountain areas Mugodzhary (the Aktyubinsk region, Kazakhstan) and in southern end of Southern Ural Mountains (the Orenburg region, Russia) mainly in joint pairs with smaller birds, specific for $A$. nipalensis orientalis.

On the basis of two recoveries of Ospreys from Upper Volga in Israel and Eritrea it is possible to assume that they winter basically in East Africa. However registration of one-year-old Osprey from Darwin Nature Reserve on Baltic (in Latvia) in spring says that, probably, some part of Ospreys

35 http://demo.nextgis.ru/birdreport/report/2944

36 http://demo.nextgis.ru/birdreport/report/2489

37 http://demo.nextgis.ru/birdreport/report/3807

38 http://demo.nextgis.ru/birdreport/report/877

39 http://demo.nextgis.ru/birdreport/report/2832

40 http://demo.nextgis.ru/birdreport/report/4

41 http://demo.nextgis.ru/birdreport/report/2860

42 http://demo.nextgis.ru/birdreport/report/2118

43 http://demo.nextgis.ru/birdreport/report/2862 
Саралинском участке Волжско-Камского государственного природного биоссерного заповедника в Республике Татарстан (Россия) был помечен кольцами М-244 и В-144 8 июня 2013 г. Ринуром Бекмансуровым $^{44}$; найден мёртвым (труп птицы, возможно, с огнестрельным ранением) на берегу Куйбышевского водохранилиша близ Жигулёвска Самарской области 15 ноября 2014 г. $^{45}$, о находке сообшили Витаиий Тоган и Антон Гушин: Аистанция 207 км, азимут - 177 градусов, продолжительность - 496 Аней.

2.5. ОАин из двух птенцов в гнезде на Куйбышевском водохранилише близ с. Куралово Республики Татарстан (Россия) был помечен кольцами М-304 и AB-304 30 мая 2014 г. Ринуром Бекмансуровым ${ }^{46}$; сротограсирован Михаилом Тимофеевым 3 января 2015 г. на зимовочном скоплении орланов близ г. Новоульяновска Ульяновской области (Россия) ${ }^{47}$ : Аистанция -122 км, азимут - 215,5 градусов, продолжительность - 219 Аней. Это уже второй возврат с этого гнезда: в 2012 г. молодой орлан из этого гнезда найден погибшим в Херсонской области Украины.

2.6. ОАин из трёх птенцов в гнезде близ с. Болгары Республики Татарстан (Россия) был помечен кольцами М-271 и АВ-271 29 мая 2014 г. Ринуром Бекмансуровым ${ }^{48}$; ссотограсрирован Михаилом Тимофеевым 3 января 2015 г. на зимовочном скоплении орланов близ г. Новоульяновска УАьяновской области (Россия) ${ }^{49}$ : Аистанция - 111 км, азимут - 207 градусов, продолжительность - 220 Аней.

2.7. ОАин из Авух птенцов в гнезде в Нацпарке "Нижняя Кама" Республики Татарстан (Россия) был помечен кольцами M-262 и АВ-262 17 июня 2013 г. Ринуром Бекмансуровым ${ }^{50}$; ссротограсрирован Михаилом Тимофеевым 3 января 2015 г. на зимовочном скоплении орланов близ г. Новоульяновска Ульяновской области (Россия $^{51}$ : Аистанция - 316 км, азимут 237 грацусов, продолжительность - 566 Аней (1 год и 7 месяцев).

2.8. ОАин из Авух птенцов в гнезде на Куйбышевском водохранилише близ с. Куралово Республики Татарстан (Россия) был помечен кольцами М-141 и АВ-041 28

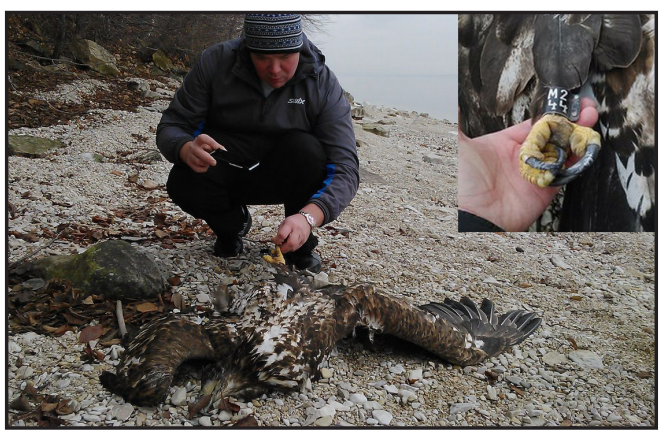

Орлан-белохвост (Haliaeetus albicilla), погибший близ г. Жигулёвск, Самарской области. Фото В. Тогана.

White-Tailed Eagle (Haliaeetus albicilla) who died near the Zhigulevsk City (Samara region). Photos by V. Togan.

from Upper Volga nevertheless winters in the Western Africa, where there are mass winterings of Ospreys, breeding in Finland (Saurola et al., 2013), from where they also migrate in spring to Baltic. Of course, while there are no direct recoveries from the Western Africa, it is only the assumption, but we will wait for the further results of ringing and GPS/SSM telemetry which will throw light on the given hypothesis.

According to messages of respondents on recoveries of Steppe Eagles, it is possible to draw a conclusion on undesirability of using the wingtags for ringing this rare species which promptly reduces its number. For a year the information on registration of 6 birds (4 from which were possible to identify) has arrived - and 3 of them were marked with wingtags in spite of the fact that part of the Steppe Eagles marked with wingtags, among total number of the marked birds is low.

In Saudi Arabia the Steppe Eagle with wingtags has been specially shot, and as mass-media informs, under the state body permission in Riyadh, in connection with an attack of spy mania - they searched for the Israeli transmitter on the bird, but didn't find it. I.e. the bird was killed for no reason in particular.

In Kenya the Steppe Eagle has been injured as a result of attack by a Pied Crow (Corvus albus), trying to tear off from it the wingtag. The eagle has been picked up by people and was delivered to the rehabilitation center in Nairobi where it goes on the mend.

In Oman as a result of confrontation be-

\footnotetext{
http://demo.nextgis.ru/birdreport/report/2075

45 http://demo.nextgis.ru/birdreport/report/2994

46 http://demo.nextgis.ru/birdreport/report/3072

47 http://demo.nextgis.ru/birdreport/report/3203

48 http://demo.nextgis.ru/birdreport/report/3063

49 http://demo.nextgis.ru/birdreport/report/3206

50 http://demo.nextgis.ru/birdreport/report/2115

51 http://demo.nextgis.ru/birdreport/report/3207
} 
Рис. 5. Схема возвратов от орланов-белохвостов (Haliaeetus albicilla), помеченных в рамках программы цветного мечения хищных птиц Российской сети изучения и охраны пернатых хишников - $A$; возвраты средневолжских орланов с зимовочного Скопления в УАьяновской области - В; орлан, помеченный в ГПКЗ "Спасский" 4 июня 2013 г. - C, D; гнезАО, в Котором он вывелся - Е (фото Р. Бекмансурова) и он же на зимовке в УАьяновской области 27 января 2015 г. (2.9) - F (сото Ф. Зелеева). Орлан, помеченный на Куйбышевском водохранияише 30 мая 2014 г. - G, H (фото P. Бекмансурова) и он же на зимовке в УАьяновской области 3 января 2015 г. (2.5) - I, J (фото М. Тимосеева). Орлан, помеченный на Куйбышевском водохранимище 28 июня 2012 г. - K, L (фото P. Бекмансурова) и он же на зимовке в УАьяновской области 3 января 2015 г. (2.8) $-\mathrm{M}, \mathrm{N}$ (фото М. Тимосреева).

Fig. 5. Recovery schemes of the White-Tailed Eagle (Haliaeetus albicilla) from the Raptor Colour Ringing Programme of the Russian Raptor Research and Conservation Network - A; recoveries of the WhiteTailed Eagles from Middle Volga Region in winter in the Ulyanovsk region - B; ringed nestlings of the White-Tailed Eagle in 4 June 2013 - C, D; nest, where he hatched $-E$ (photos by $R$. Bekmansurov) and he is wintering in the Ulyanovsk region in 27 January 2015 (2.9) - $F$ (photo by

F. Zeleev). Ringed nestlings of the White-Tailed Eagle in 30 May 2014 - G, H (photos by R. Bekmansurov) and he is wintering in the Ulyanovsk region in 3 January 2015 (2.5) - I, J (photos by M. Timofeev). Ringed nestlings of the White-Tailed Eagle in 28 June 2012 - K, $L$ (photos by $R$. Bekmansurov) and he is wintering in the Ulyanovsk region in 3 January 2015 (2.8) - M, N (photos by M. Timofeev)

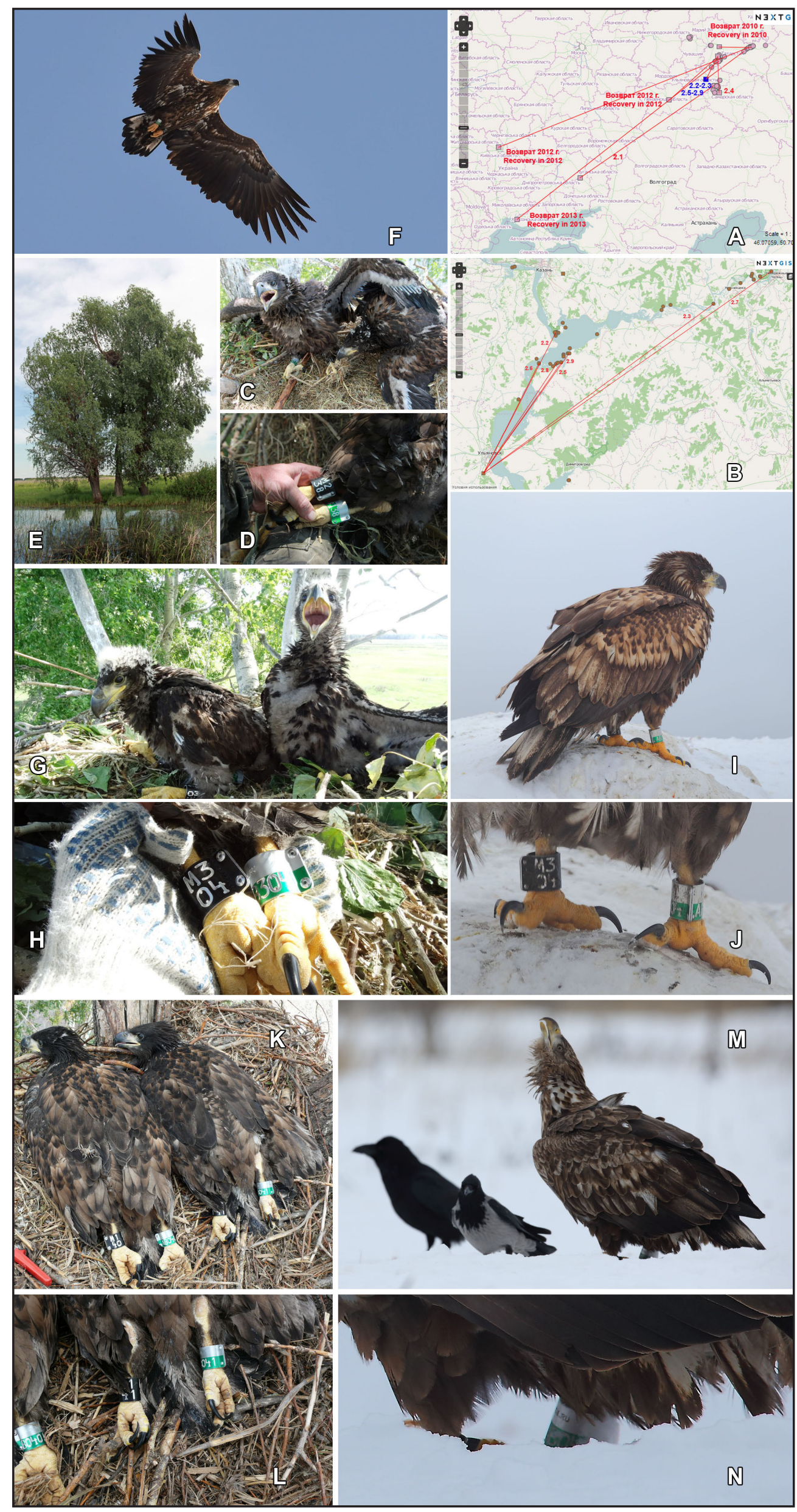


июня 2012 г. Ринуром Бекмансуровым ${ }^{52}$; сфотограсрирован Михаилом Тимофеевым 3 января 2015 г. на зимовочном скоплении орланов близ г. Новоульяновска Ульяновской области (Россия) ${ }^{53}$ : Аистанция - 120 км, азимут - 214 градусов, продолжительность - 920 Аней (2,5 года). Этот орлан и орлан с кольцами M-304+AB-304 (2.5) - соседи. Между гнёздами, в которых они вывелись, расстояние всего 3,7 км (оба гнезда разных пар орланов располагаются на одном острове).

2.9. ОАин из Авух птенцов в гнезде на Куйбышевском водохранилише в ГПКЗ "Спасский" Республики Татарстан (Россия) был помечен кольцами М-238 и АВ-138 4 июня 2013 г. Ринуром Бекмансуровым ${ }^{54}$; сротограсрирован Фаритом Зелеевым 27 января 2015 г. на зимовочном скоплении орланов близ г. Новоульяновска Ульяновской области (Россия) ${ }^{55}$ : Аистанция - 133 км, азимут - 216 градусов, продолжительность - 601 Аень (почти 2 года).

\section{3. Орёл-могильник (Aquila heliaca)}

3.1а. Птенец в гнезде близ с. Николькое Спасского р-на Республики Татарстан (Россия) был помечен кольцами В-75 и АА-2921 16 июля 2013 г. Ринуром Бекмансуровым ${ }^{56}$; ссротограсрирован Майком Барсом (Mike Barth) 4 января 2014 г. в ОАЭ ${ }^{57}$ : Аистанция - 3375 км, азимут - 169 грахусов, продолжительность - 173 Аня.

3.1б. Этот же молодой могильник С кольцами В-75 и АА-2921 ссотограсрирован в ОАЭ Майком Барсом (Mike Barth) и Мишелем Веласко (Michael Velasco) 13 ноября 2014 г. ${ }^{58}$, затем Фуахом Итани (Fouad Itani) 2 февраяя 2015 г. ${ }^{59}$ : Аистанция - 3375 км, азимут - 169 грацусов, продолжительность - 567 Аней (1,5 года, вторая зимовка в том же месте).

3.2. Птенец в гнезде близ с. Балтачево Азнакаевского р-на Республики Татарстан (Россия) был помечен кольцами В-38 и АВ-0389 12 июля 2012 г. Ринуром Бекмансуровым ${ }^{60}$; найден мёртвым (труп птицы с огнестрельным ранением) близ ст. Незлобная Георгиевского района Ставропольского края 2 марта 2014 г. $^{61}$ : Аис- tween a Steppe Eagle with wingtag and an Imperial Eagle, the last has pulled out from a wing the wingtag, obviously having damaged a bird patagium. Picked up wing tab was all in damages and without a code that says that it was repeatedly exposed to aggressive influence from the outside.

Considering that wingtags obviously complicate the life of Steppe Eagles with the absence of more progressive scientific output from this method, in comparison with safe tagging, it is necessary to bring for discussion a question about the necessity of using the wingtags for tagging a Steppe Eagle further. The question about necessity of tagging with wingtags already rose at conference "Eagles Palaearctic..." and by results of the discussion, in the resolution of a round table "Ringing methods of feathery predators (satellite and GSM transmitters, color ringing, etc.)" the decision of participants has been fixed "with care to use wing tabs in programs of ringing, preliminary estimating pluses and minuses, and also efficiency of this method". Also participants recommended adopting the best practices of colleagues from Kazakhstan, who use modified wing tab which is put on a brush and does not injure a wing and is more wearproof (Outcomes ..., 2013).

In 2014 fragility of plastic rings on large eagles, such as Imperial and Steppe Eagles was confirmed. In 10 cases from 29 of eagle registration plastic rings have been lost by them. I.e. it is possible to assume that not less than $30 \%$ of eagles for 3 years could lose rings, and, some part of birds has lost them already during the first year. From here it is possible to draw a conclusion that it is better for eagles to ring them with color aluminum rings and the course on full refusal of plastic in ringing the eagles was taken correctly. It does not concern the Spotted Eagles for which the loss of plastic rings is not established yet.

\section{Conclusion}

Unfortunately, till now in many regions of Russia and Kazakhstan color ringing of raptors is not conducted, though ringing by

\footnotetext{
http://demo.nextgis.ru/birdreport/report/895

3 http://demo.nextgis.ru/birdreport/report/3786

http://demo.nextgis.ru/birdreport/report/2069

5 http://demo.nextgis.ru/birdreport/report/3787

http://demo.nextgis.ru/birdreport/report/2196

7 http://demo.nextgis.ru/birdreport/report/2831

s http://demo.nextgis.ru/birdreport/report/2993

http://demo.nextgis.ru/birdreport/report/3791

o http://demo.nextgis.ru/birdreport/report/917

http://demo.nextgis.ru/birdreport/report/2834
} 


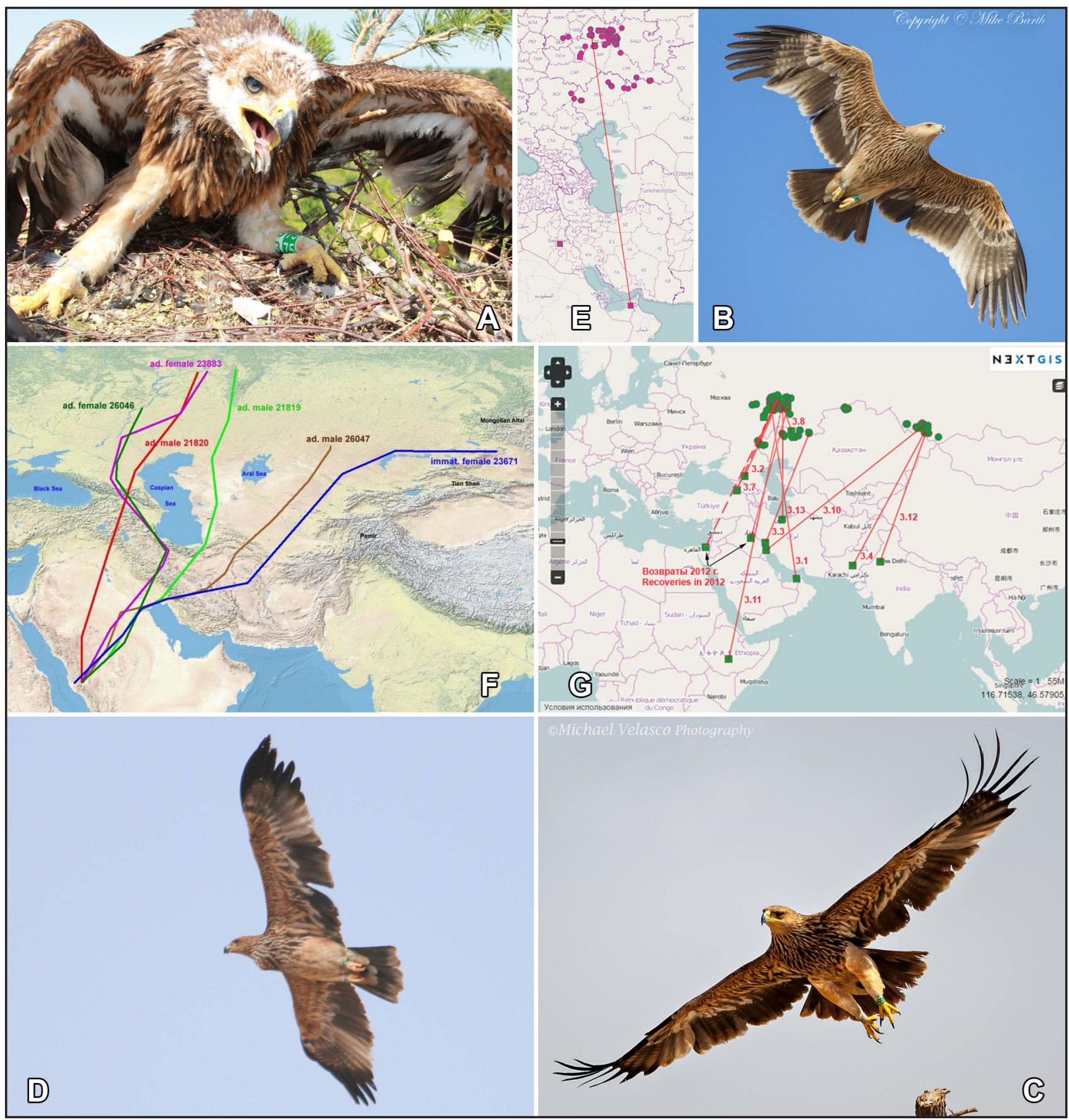

Pис. 6. Орёл-могильник (Aquila heliaca), помеченный кольцами B-75 и АA-2921 в Татарстане (Россия) в 2013 г. - A (фото Р. Бекмансурова), он же на своей первой зимовке в ОАЭ в январе 2014 г. - В (фото М. Барса), на второй зимовке там же в ноябре 2014 г. - С (фото М. Веласко) и в феврале 2015 г. - D (фото Ф. Итани), схема возврата этого орла - E; маршруты орлов-могильников, помеченных спутниковыми передатчиками, из: Meyburg, 2015; схемы возвратов от орлов-могииьников, окольцованных в рамках программы цветного мечения хишных птиц Российской сети изучения и охраны пернатых хишников в 2012-2014 гг. - G.

Fig. 6. Eastern Imperial Eagle (Aquila heliaca) with rings B-75 and AA-2921 in the Republic of Tatarstan (Russia) in 2013 - A (photo by $R$. Bekmansurov), it on the first wintering in the United Arab Emirates in January, 2014 - B (photo by $M$. Barth), on the second wintering in the same place in November, $2014-C$ (photo by M. Velasco) and in February, $2015-D$ (photo by F. Itani), the scheme of recovery of this eagle $-E$; routes of the imperial eagles marked with satellite transmitters, from: Meyburg, 2015; schemes of recoveries of Imperial Eagle, ringed within the limits of the Raptor Color Ringing Program of the Russian Raptor Research and Conservation Network in 2012-2014 - G.

танция - 1375 км, азимут - 214 грахусов, продолжительность - 599 Аней (1 год и 6,5 месяцев).

3.3. ОАин из трёх птенцов в гнезде на самом севере Актюбинской области Казахстана недамеко от границы с Оренбуржьем standard rings is carried out. Standard rings are calculated only on capture of a bird or finding the lost bird as to read a full code on such ring is possible only having a bird in hands. Color rings allow reading a code on live birds from a distance. Nowadays at 
в 40 км к юго-западу от г. Орск (Россия) был помечен кольцом АК-1013-1М 30 июня 2013 г. Игорем Карякиным ${ }^{62}$; найАен раненым (огнестрельное ранение) 30 января 2014 г. в провинции Хузестан в Иране недалеко от города Шуши (этот город стоит на месте Аревнего города Сузы Персидской империи на краю гор Загрос около 250 км к востоку от реки Тигр), сообшия Мохаммахреза Энамоуй (Mohammadreza Enaloui) $^{63}$ : дистанция 2234 км, азимут - 205 градусов, продолжительность - 215 дней. Птица возврату в природу не подежит. В настояшее время содержится в центре при охраняемой территории на месте кАючевой орнитологической территории международного значения IR058 "Karkheh river marshes" в 50 км к северо-северо-западу от города Ахваз.

3.4. Птенец в гнезде в Усть-Канской котмовине Республики Алтай (Россия) был помечен кольцами А-58 и АВ-0682 9 июля 2013 г. Алексеем Карповым ${ }^{64}$; найден ослабленным и пойман в Пакистане в окрестностях Аарканы (larkana, Sindh) 15 феераля 2014 г., передан в реабилитационный центр в Белуджистане, сообшил Насир Якуб (Nasir Yaqoob) ${ }^{65}$ : Аистанция 2957 км, азимут - 214,5 грахусов, продолжительность - 222 Аня.

3.5. ОАин из Авух птенцов в гнезде на юге Аениногорского района Республики Татарстан (Россия) был помечен кольцами С-070 и АА-0070-6А 5 июля 2014 г. Ринуром Бекмансуровым ${ }^{66}$; найден мёртвым (вероятно отравление) на гнездовом участке (близ с. Акбаш Бугульминского района Республики Татарстан) Сергеем Матвеевым 2 сентября 2014 г. ${ }^{67}$ : Аистанция - 2,2 км, азимут - 186 грацусов, продолжительность - 60 Аней (2 месяца).

3.6. Птенец в гнезде близ Новошешминска в Шешминском районе Республики Татарстан (Россия) был помечен кольцами С-098 и АА-0098-9А 14 июля 2014 г. Ринуром Бекмансуровым ${ }^{68}$; 3 сентября 2014 г. найден мёртвым на гнездовом участке под опорой минии электропереАачи 10 кВ со штыревыми изоляторами (погиб от поражения электротоком, киния принацлежит ЗАО «Троицкнесть»), price availability of phototechnics of the high resolution and the telephoto lenses, many birdwatchers and simple photographers can receive high-quality photos of ringed birds. On these photos it is easy to read not only a color, but also a ring code. Practice of supervision over birds in telescopes extends recently that also allows to read a code on a ring and even to receive photo of such fact, having photographed a bird through a telescope with the simple compact camera or the camera which has been built in the smartphone.

Color ringing is a useful method of research of not only migrations, but also philopatry, demography, ecology, behavior and etc. Use of color rings in addition or instead of usual metal rings considerably raises Efficiency of ringing as method. Reading a ring without necessity of catching a bird reduces the research press and lowers the level of stress put by the researcher. Moreover, the ring can be read by different researchers rather easily and many times during the life of a bird that allows to collect more data and to improve researches.

The same is possible to tell about aluminum rings with the double painted code which have wide prospects of introduction in practice of ringers instead of usual rings. On such rings it is extremely important to have not only a large readable code, but also the clear and understandable data about the ringing center which can be found in the Internet. Better, if it is the web-site and/or e-mail address.

Experience of our program shows the importance of a digital photo in supervision of birds, especially by birdwatchers as it considerably increases the quantity of returns, and also the importance of drawing on rings the address of a site through which the basic information on returns of the caught or lost birds comes.

In the conclusion we would like to note the necessity of coordination of ringers and agreement of color ringing schemes. We appeal to all who wants to join in the program, to address in the Raptor Ringing Center for the operative coordination of color ringing schemes for raptors with the coordination centers in Europe and Asia. 
сообшили Иван и Галина Сергеевы ${ }^{69}: \Delta и с-$ танция - 2,7 км, азимут - 296 градусов, продолжительность - 52 Аня.

3.7. Молодой могильник, помеченный в Татарстане в 2014 г. сфотографирован Ажоном Райтом (John Wright) 15 октября 2014 г. в Грузии недалеко от Батуми ${ }^{70}:$ Аистанция - около 1600 км, азимут - около 213 грахусов, продолжительность - примерно 100 Аней.

3.8. ОАин из Авух птенцов в гнезде око10 А. Китьельга Аиьметьевского района Республики Татарстан (Россия) был помечен кольцами С-094 и АА-0094-9А 13 июля 2014 г. Ринуром Бекмансуровым ${ }^{71}$; найден мёртвым под опорой кинии электропереАачи 10 кВ со штыревыми изоляторами (погиб от поражения электротоком, миния приначмежит РЖА) Тимуром Рзашевым 22 октября 2014 г. близ границы России и Казахстана между Новоилецком и Аиневкой Оренбургской области ${ }^{\mathbf{7 2}}$ : Аистанция - 463 км, азимут - 158 градусов, продолжительНОСть - 102 Аня.

3.9. ОАин из Авух птенцов в гнезде около с. Потапово-Тумбарла Бавлинского района Республики Татарстан (Россия) был помечен кольцами С-072 и АА-00727А 6 июля 2014 г. Ринуром Бекмансуровым ${ }^{73}$; погиб на гнезАовом участке от поражения электротоком на минии электропередачи 10 кВ со штыревыми изомяторами, запитываюшей нестекачамку ПАО "Татнестть". Труп птицы повис на анкерной опоре АЭП, откуда был снят энергетиками "Бавлынесть" и брошен в лесу 25 ноября 2014 г., о чём сообшил Ильнар Садыков ${ }^{74}$ : Аистанция - 0,26 км, азимут - 185 градусов, продолжительность - менее 140 Аней.

3.10. ОАин из Авух птенцов в гнезде око^о А. Черемшанка Солонешенского района Алтайского края (Россия) был помечен кольцами В-53 и АA-2353 и GSM/GPS передатчиком 21 июля 2014 г. Сергеем Важжовым, Романом Бахтиным, Матьяшом Проммером (Matyas Prommer), Мартоном Хорватом (Marton Horvath) и Тибо- ром Юхашом (Tibor Juhasz) ${ }^{75}$; подобран под АЭП с поврежденным крылом (вероятно, столкновение с проводами) 11 декабря 2014 г. в землелельческом районе в провинции Хузестан (Иран), отправлен на лечение, о чём сообшил Салех Салеги Зацеган (Sadegh Sadeghi Zadegan) ${ }^{76}$ : $и и с-$ танция - 3754 км, азимут - 245 грахусов, продолжительность - 144 дня (по Аанным телеметрии орёл пролетел 3941 км, генераиьный азимут миграции - 245 градусов). 27 января 2015 г. этот орёл-могильник выпушен на свободу.

3.11. Птенец в гнезде около с. Нижние Чершилы Республики Татарстан (Россия) был помечен кольцами В-144 и АВ-01444В 4 июля 2014 г. Ринуром Бекмансуровым ${ }^{77}$; найден погибшим (причина не известна) 16 февраля 2016 г. в Нацпарке Бами (Bale Mountains National Park) в Эсриопии, о чём сообшил Мэтью Торнтон (Matthew Thornton) $^{\mathbf{7 8}}$ : Аистанция - 5385 км, азимут - 196 градусов, продолжительность - 228 Аней.

3.12. ОАин из Авух птенцов в гнезде в УстьКанской котловине Республики Аитай (Россия) был помечен кольцами A-26 и AB-0605 2 июля 2013 г. Алексеем Карповым 79; найден ослабленным (вероятно, после отравления) на окраине с. Сардаршахар в провинции Рацжастан (Индия) 1 февраия 2015 г., о чём сообшил Харкират Санга (Harkirat Sangha) ${ }^{\mathbf{8 0}}$ : Аистанция - 2654 км, азимут - 203 грауусов, продолжительность - 580 дней (1,5 года). 16 марта 2015 г. этот орёл-могильник выпушен на свободу в заповеднике Таи Чхапар (Tal Chhapar Sanctuary).

3.13. ОАин из Авух птенцов в гнезде близ с. Верхние Чершилы Лениногорского района Республики Татарстан (Россия) был помечен кольцами С-062 и АА-0062-6А 3 июля 2014 г. Ринуром Бекмансуровым ${ }^{81}$; 30 апреля 2015 г. найден разложившийся труп орла в Иране на побережье Каспийского моря в окрестностях с. Нур провинции Мазендеран (Nur, Mazandaran), о чём сообшил Бахман Теграни (Bahman Tehrani) $^{82}$ : Аистанция - 2012 км, азимут -

69 http://demo.nextgis.ru/birdreport/report/2933

70 http://demo.nextgis.ru/birdreport/report/2945

71 http://demo.nextgis.ru/birdreport/report/2926

72 http://demo.nextgis.ru/birdreport/report/2931

73 http://demo.nextgis.ru/birdreport/report/2996

74 http://demo.nextgis.ru/birdreport/report/2995

75 http://demo.nextgis.ru/birdreport/report/3043

76 http://demo.nextgis.ru/birdreport/report/3090

77 http://demo.nextgis.ru/birdreport/report/3224

78 http://demo.nextgis.ru/birdreport/report/3792

79 http://demo.nextgis.ru/birdreport/report/2212

so http://demo.nextgis.ru/birdreport/report/3793

81 http://demo.nextgis.ru/birdreport/report/3216 
180 градусов, продолжительность - менее 300 Аней.

3.14. Также Фуах Итани (Fouad Itani) в ноябре 2014 г. в ОАЭ 83 ссотограсрироваи орла-могильника с кольцом совместной программы Российской сети изучения и охраны пернатых хишников и Казахстанского центра кольцевания птиц, однако из-за большого расстояния коА с кольца считать не Аалось (второе кольцо на птице отсутствовало). Тем не менее, можно определённо сказать, что этот орёл-могильник был окольцован в Западном Казахстане в 2013 г.

\section{4. Степной орёл (Aqula nipalensis)}

4.1. ОАин из Авух птенцов в гнезде близ с. Катричев Волгоградской области (Россия) был помечен кольцами А-22 и АA0497 и крылометками S7 3 июля 2013 г. Валерием Пименовым ${ }^{84}$; был добыт в Саудовской Аравии на границе с Ираком 14 октября 2014 г., о чём сообшил Калифа Аиь $\triangle$ ахери (Khalifa Al Dhaheri) ${ }^{85}$ - по сообшениям СМИ птица была отстрелена по разрешению госоргана Эр-Рияла из-за поАозрения, что на ней израильский переАатчик $^{86,87}$ : Аистанция - 2101 км, азимут - 188 градусов, продолжительность - 469 Аней (1 гоА и 3 месяца).

4.2. ОАин из Авух птенцов в гнезде в отрогах Тамдуаира к северо-востоку от Ташанты и к западу от оз. Киндикты-Куль в Кош-Агачском районе Республики Алтай (Россия) был помечен кольцами С-029 и AА-0029-2A 25 июля 2014 г. Игорем Карякиным, Эльвирой Николенко, Еленой Шнайдер, Матьяшом Проммером (Matyas Prommer), Мартоном Хорватом (Marton Horvath) и Тибором Юхашом (Tibor Juhasz)88; 22 ноября 2014 г. был найден мёртвым в Иране около Бардаскана ${ }^{89}$ : танция - 3013 км, азимут - 249 грахусов, продолжительность - 121 Аень.

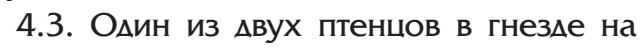
Сайлюгеме к запалу от Ташанты в КошАгачском районе Республики Алтай (Россия) был помечен кольцами С-019 и

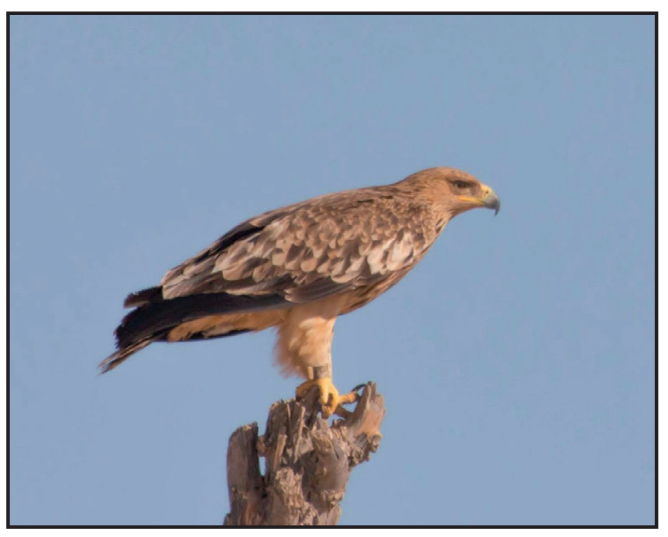

Орёл-могильник (Aquila heliaca) с казахстанским кольцом в ОАЭ. Фото Ф. Итани.

Imperial Eagle (Aquila heliaca) with Kazakhstan's ring in the UAE. Photo by F. Itani.

АA-0019-1А 14 июля 2014 г. Игорем Карякиным, Эльвирой Николенко, Еленой Шнайдер ${ }^{90}$; 7 мекабря 2014 г. был отловлен в Иране к югу от Аеррегеза (это пара десятков километров от границы с Туркменистаном) ${ }^{91}$ : Аистанция - 2758 км, азимут - 251,5 градус, продолжительность - 147 мней. Орёл попаи в реабимитационный чентр, после чего была выпушен в природу.

4.4. ОАин из трёх птенцов в гнезде близ с. Сацчиков Волгограцской области (Россия) был помечен кольцами А-17 и АА2217 и крылометками W8 5 июля 2014 г. Валерием Пименовым и Михаилом Байбаковым92; 23 января 2015 г. птица поАобрана местными жителями в Найроби (Кения) и доставлена в реабилитационный центр, о чём сообшила Зоя Гиббс (Zoe Gibbs) ${ }^{93}$. Как рассказаяи спасители птицы, её атаковая пегий ворон (Corvus albus) в попытке сорвать с орла крылометку орёл упал на землю и получил ушибы: Аистанция - 5719 км, азимут - 192 грахуса, продолжительность - 203 дня. После реабилитации, 2 марта 2015 г. орёл выпушен на свободу.

4.5. ОАин из двух птенцов в гнезде в 9 км к

\footnotetext{
http://demo.nextgis.ru/birdreport/report/3804

s3 http://rrrcn.ru/forum/viewtopic.php?f=4\& $t=1928$ start=30\#p2047

84 http://demo.nextgis.ru/birdreport/report/2381

85 http://demo.nextgis.ru/birdreport/report/2924

86 http://www.ow-news.com/news.php?action=show\& $i d=17958$

87 http://www.palnnn.com/?p=42767

88 http://demo.nextgis.ru/birdreport/report/3528

89 http://demo.nextgis.ru/birdreport/report/3802

90 http://demo.nextgis.ru/birdreport/report/3505

91 http://demo.nextgis.ru/birdreport/report/3801

92 http://demo.nextgis.ru/birdreport/report/3652

93 http://demo.nextgis.ru/birdreport/report/3788
} 
Рис. 7. Схема возвратов степных орлов (Aquila nipalensis) - A; птенцы степного орла во время мечения от которых получены возвраты $4.5-B$ 4.3 - С и 4.2 - D (фото И. Карякина). Птенец степного орла во время мечения 3 июля 2013 г. -F (фото В. Пименова) и он же Аобытый в Саудовской Аравии 14 октября 2014 г. (4.1) - E (фото из ow-news). Схема натаиьного возврата степного орла на втором году жизни из Аитайского края (4.6) - G. Этот орёл с кольцом серии А у с. Огни 29 апреля 2015 г. - H (фото С. Важова). Степные орлы с кольцами серии А, помеченные в Чарышской степи 20 июля 2013 г. - I, J (рото С. Важова и Р. Бахтина).

Fig. 7. Recovery schemes of the Steppe Eagle (Aquila nipalensis) - $A$; ringed nestlings of the Steppe Eagle from which recoveries were obtained: $4.5-B, 4.3-C$ and $4.2-D$ (photos by $I$. Karyakin). Ringed nestlings of the Steppe Eagle in 3 July 2013 - F (photo by V. Pimenov) and his recovery in the Saudi Arabia in 14 October 2014 (4.1) - E (photo from ow-news). Recovery scheme of the Steppe Eagle in the second year in the natal area of the Altai Kray (4.6) - G. The same Steppe Eagle with the ring A-series near Ogni village in 29 April 2015 - H (photo by S. Vazhov). Steppe Eagles with rings Aseries in the Charysh steppe in 20 July 2013 - I, J (photos by S. Vazhov and R. Bachtin).
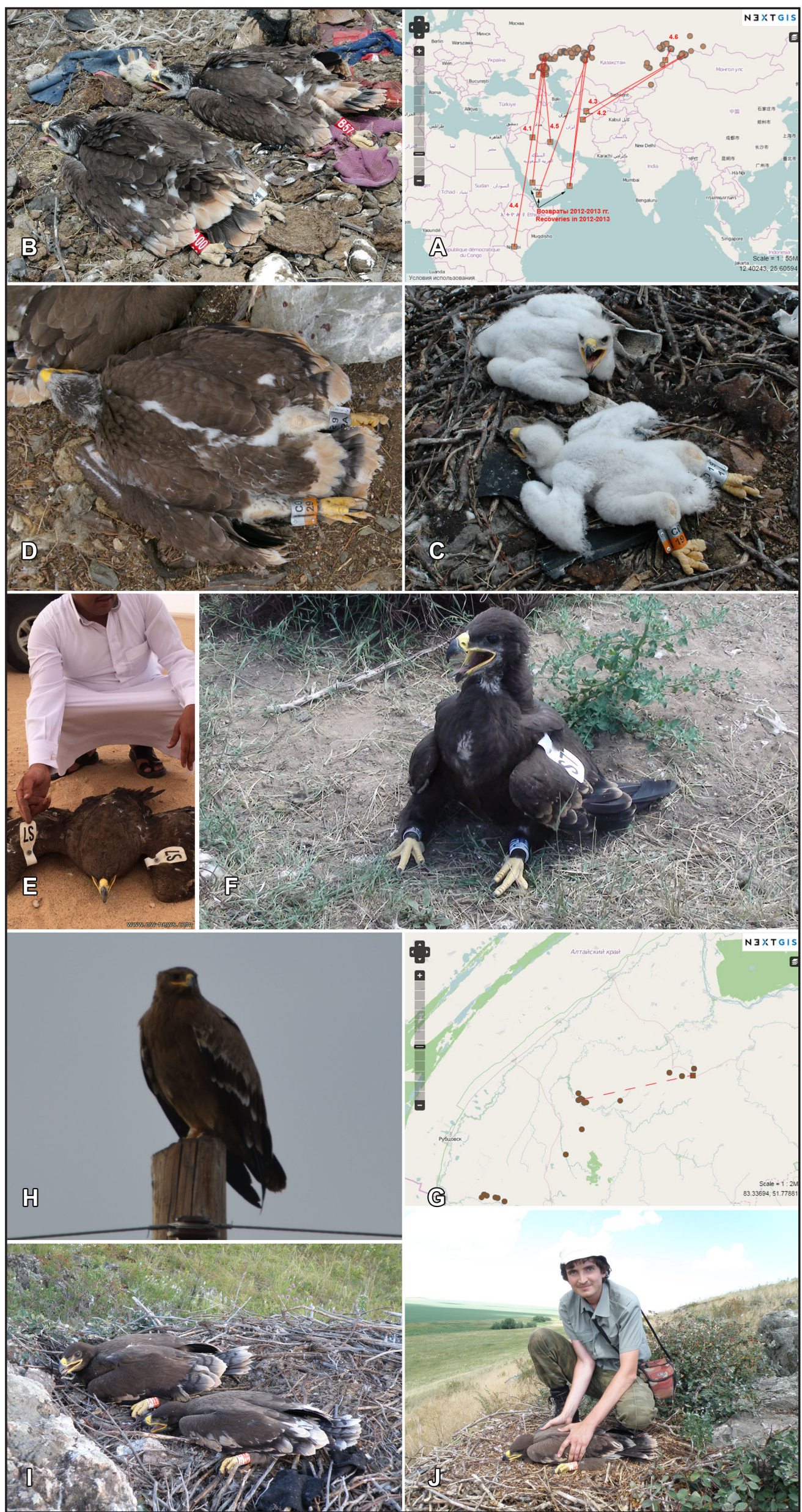
юго-востоку от п. Привольный в Республике Каимыкия (Россия) был помечен кольцами A-00 и AB-0610 12 июня 2013 г. Игорем Карякиным4; 12 марта 2015 г. этот орёл был пойман в Кувейте, о чём сообшил Абдума Аиькааби (Abdulla Alkaabi) ${ }^{95}$ : Аистанция 1920 км, азимут - 174 грахуса, продолжительность - 639 Аней (1 год и 9 месяцев). Пиастиковое кольцо орлом было утеряно, Ааиьнейшая судьба птицы неизвестна.

4.6. Птенец, помеченный Сергеем Важовым и Романом Бахтиным на одном из гнёзА в Чарышской степи Алтайского края (Россия) 20 июля 2013 г., сротограсрирован ими же недамеко от с. Огни Алтайского края 29 апреля 2015 г. ${ }^{96} \mathrm{~K}$ сожалению точно код кольца с фотограсии считать невозможно. Орёл был помечен мибо кольцами А-10 и АВ-047897, мибо A-11 и АВ-047998 - расстояние межАу гнёздами, на которых были помечены эти птенцы, составляет 8 км: Аистанция 72,5 км (ими 76,5 км мия А-11+АВ-0479), азимут 75 грахусов (или 80 грахусов мия А-11+АВ-0479), продолжительность 649 Аней (1 год и 8 месяцев).

\section{5. Курганник (Buteo rufinus)}

5.1. ОАин из четырёх птенцов в гнезде близ с. Катричев Волгогралской области (Россия) был помечен кольцами D-10 и BS-005910 и Авусторонними крылометками с буквой N 13 июня 2013 г. Вамерием Пименовым99; обнаружен мёртвым 25 февраля 2014 г. около п. Южный Городовиковского района Республики Калмыкия (Россия) председателем местного обшества охотников и рыболовов В.Х. Абушиновым ${ }^{100}$ : Аистанция - 452 км, азимут - 217,8 градусов, продолжительность - 258 Аней.

5.2. ОАин из пяти птенцов в гнезде близ с. Катричев Волгограхской области (Россия) был помечен крылометками с кодом F4 15 июня 2012 г. Валерием Пименовым $^{101}$; найден мёртвым под опорой минии электропередачи 10 кВ со штыревыми изоляторами (погиб от поражения электротоком) близ Новоалександровска Ставропольского края 30 января 2015 г. (сообщение получено через Golden Eagle Trust) ${ }^{102}$ : Аистанция - 554 км, азимут - 219 грацусов, продолжительность - 960 Аней (2 года и 6 месяцев).

5.3. ОАин из четырёх птенцов в гнезде, расположенном в 30 км к северу от Эльтона Волгогралской области (Россия) был помечен кольцом BS-005996 11 июня 2014 г. Валерием Пименовым и Михаилом Байбаковым ${ }^{103}$; найден мёртвым (вероятно погиб на АЭП рялом с летним лагерем скота, останки расташены и съедены четвероногим хишником) близ А. Бесскоробная, Новокубанского р-на, Краснодарского края 31 января 2015 г. (сообшение получено через Российский центр кольцевания птиц $)^{104}$ : Аистанция - 665 км, азимут - 218 гралусов, продолжительность - 235 дней.

\section{6. Балобан (Falco cherrug)}

6.1. ОАин из пяти птенцов в гнезде в Тувинской котловине Республики Тыва (Россия) был помечен кольцами D-156 и С-541356 13 июня 2014 г. Игорем Карякиным, Эльвирой Николенко и Еленой Шнай $\mathrm{ep}^{105}$; обнаружен мёртвым разложившийся труп птицы был найден в Кыгинском заливе на Телецком озере в Республике Алтай (Россия) И. Чупиным 2 октября 2014 г. ${ }^{106}$ : Аистанция - 473 км, азимут - 270 градусов, продолжительность - 112 дней (Карякин и Ар., 2014).

\section{7. Фикин (Bubo bubo)}

7.1. ОАин из двух птенцов в гнезде в Чарышской степи Алтайского края (Россия) был помечен кольцами В-71 и АА-2468 28 мая 2014 г. Сергеем Важовым и Романом Бахтиным ${ }^{107}$; обнаружен мёртвым 16 декабря 2014 г. в кустах у реки в г. Шемонаиха (Казахстан) Алексеем Журавлёвым $^{108}$ : Аистанция - 129 км, азимут -

\footnotetext{
94 http://demo.nextgis.ru/birdreport/report/1701

95 http://demo.nextgis.ru/birdreport/report/3797

96 http://demo.nextgis.ru/birdreport/report/3880

97 http://demo.nextgis.ru/birdreport/report/2182

98 http://demo.nextgis.ru/birdreport/report/2183

99 http://demo.nextgis.ru/birdreport/report/2445

100 http://demo.nextgis.ru/birdreport/report/2835

101 http://demo.nextgis.ru/birdreport/report/1496

102 http://demo.nextgis.ru/birdreport/report/3795

103 http://demo.nextgis.ru/birdreport/report/3773

104 http://demo.nextgis.ru/birdreport/report/3796

105 http://demo.nextgis.ru/birdreport/report/3030

106 http://demo.nextgis.ru/birdreport/report/3031

107 http://demo.nextgis.ru/birdreport/report/3026

108 http://demo.nextgis.ru/birdreport/report/3027
} 

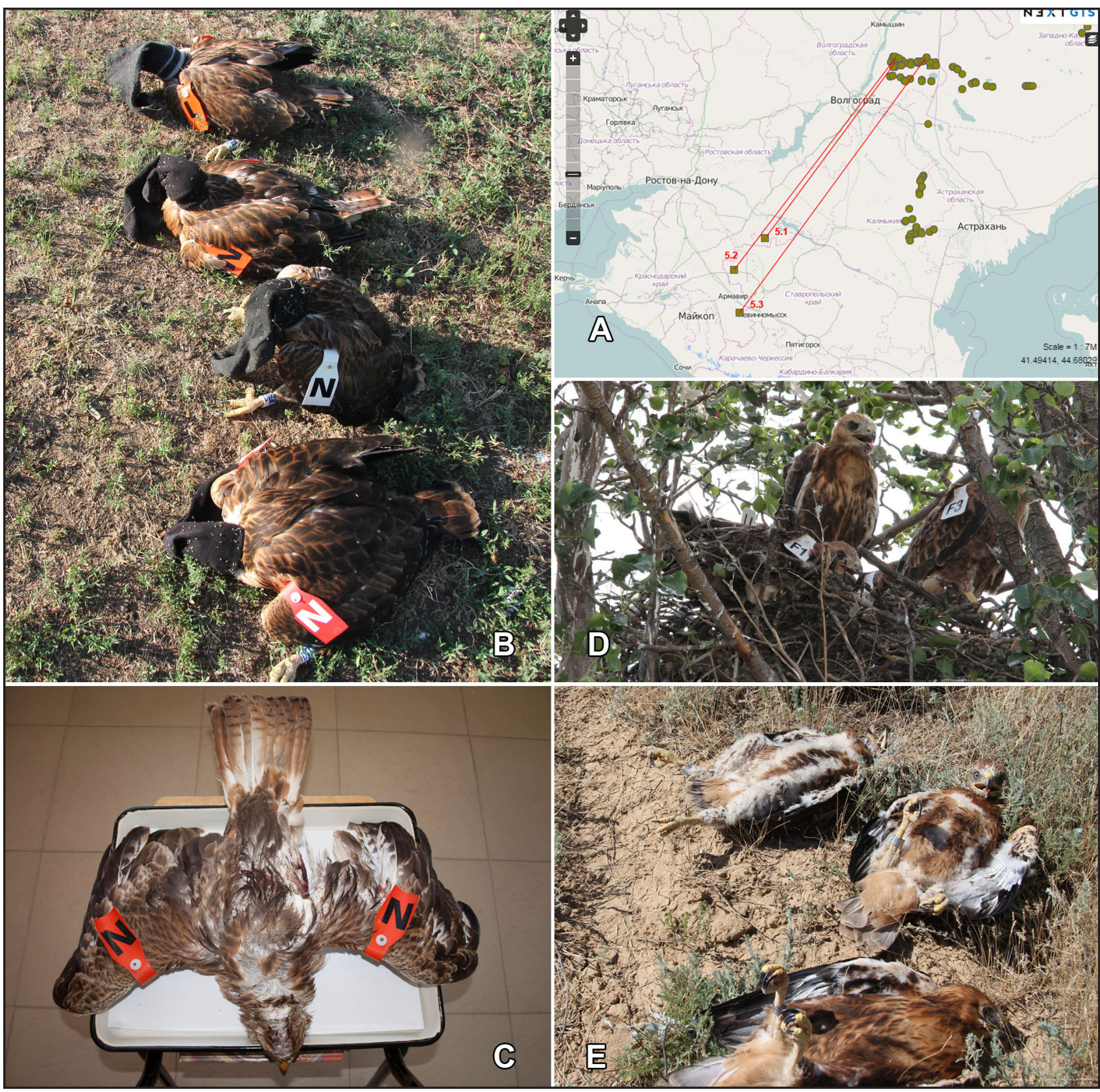

Рис. 8. Схема возвратов курганников (Buteo rufinus) - A; птенцы курганника во время мечения 13 июня 2013 г. - В (фото В. Пименова) и возврат одного из птенцов с этого гнезда из Каммыкии (5.1) - С (фото Б. Убушаев); птенцы курганника во время мечения, от которыХ получены возвраты 5.2 - D и $5.3-E$ (фото В. Пименова).

Fig. 8. Recovery schemes of the Long-Legged Buzzards (Buteo rufinus) - A; ringed nestlings of the Long-Legged Buzzards in 13 June 2013 $-B$ (photo by V. Pimenov) and recovery of one of the nestling from this nest in the Republic of Kalmykia (5.1) - C (photo by B. Ubushaev); ringed nestlings of the Long-Legged Buzzards from which recoveries were obtained: $5.2-D$ and $5.3-E$ (photos by V. Pimenov).

198,6 градусов, продолжительность - 203 Аня (Карякин, 2014).

\section{Возвраты зарубежных птиц у нас \\ 1. Скопа (Pandion haliaetus)}

1.4. Птица с финским кольцом N-5677 сфотограсирована фотоловушкой, установленной Мирославом Бабушкиным 12 апреля 2014 г. на одном из гнёзд в гнезАовой группировке скоп в Аарвинском государственном природном биоссерном заповеднике (Россия) ${ }^{109}$. К сожамению полностью коА кольца прочитать не удалось, скопа была сротограсрирована однократно (видимо, на миграции) и больше не попадаяась наблюдателям.

\section{Обсужиение}

Анамиз встреч живых птиц и находок мёртвых и травмированных маёт инфор- 
мацию по нескольким важным вопросам:

1) причины гибели и травмирования птиц, т.е. их уязвимость на путях миграции;

2) направления и расстояния миграции, места зимовок и остановок на пути;

3) продолжительность жизни - как минимум, до даты встречи, а также уязвимая возрастная группа;

4) зависимость причин смерти или травмирования от направления и дистанции миграции.

Кроме того, анализируя эти случаи, т.е. получая обратную связь от вложенных усилий, можно понять, какие методы мечения, а также информирования населения и сбора информации о встречах лучше работают, что позволяет их скорректировать и улучшить результативность работы. Более того, мы узнаём, как относятся к хищным птицам кюди разных регионов, стран и социальных групп, налаживаются контакты межАу ^юбителями птиц, а также мы видим, что встреча, а тем более наход- ка птицы с кольцом, работает и как метод экологического просвешения, когАа АюАи начинают прилагать усилия рахи птиц и их спасения.

Среди птиц, о которых была получена инсормация, мидируют орёл-могильник (14 особей) и орлан-белохвост (9 особей) (табл. 5).

Только 3 из 14 могильников были серотограсированы (встречены живыми), 4 ослабленных или травмированных были подобраны людьми и переданы в центры реабилитации, 2 из которых были возвращены в природу, половина же (7 из 14) были найдены мёртвыми, 3 из которых погибли на АЭП, один отстрелян, ешё один, вероятно, отравлен, а причины гибели Авух остались не известны. Обрашает на себя внимание тот факт, что, разлетаясь достаточно широко от Афррики $А$ Индии, птицы были сфотограсированы 3 раза в ОАЭ, переданы на реабилитацию в Иране (2 случая), Пакистане (1 случай) и Индии

Табл. 5. Характер ицентисрицированных возвратов.

Table 5. The characteristic of the identified recoveries.

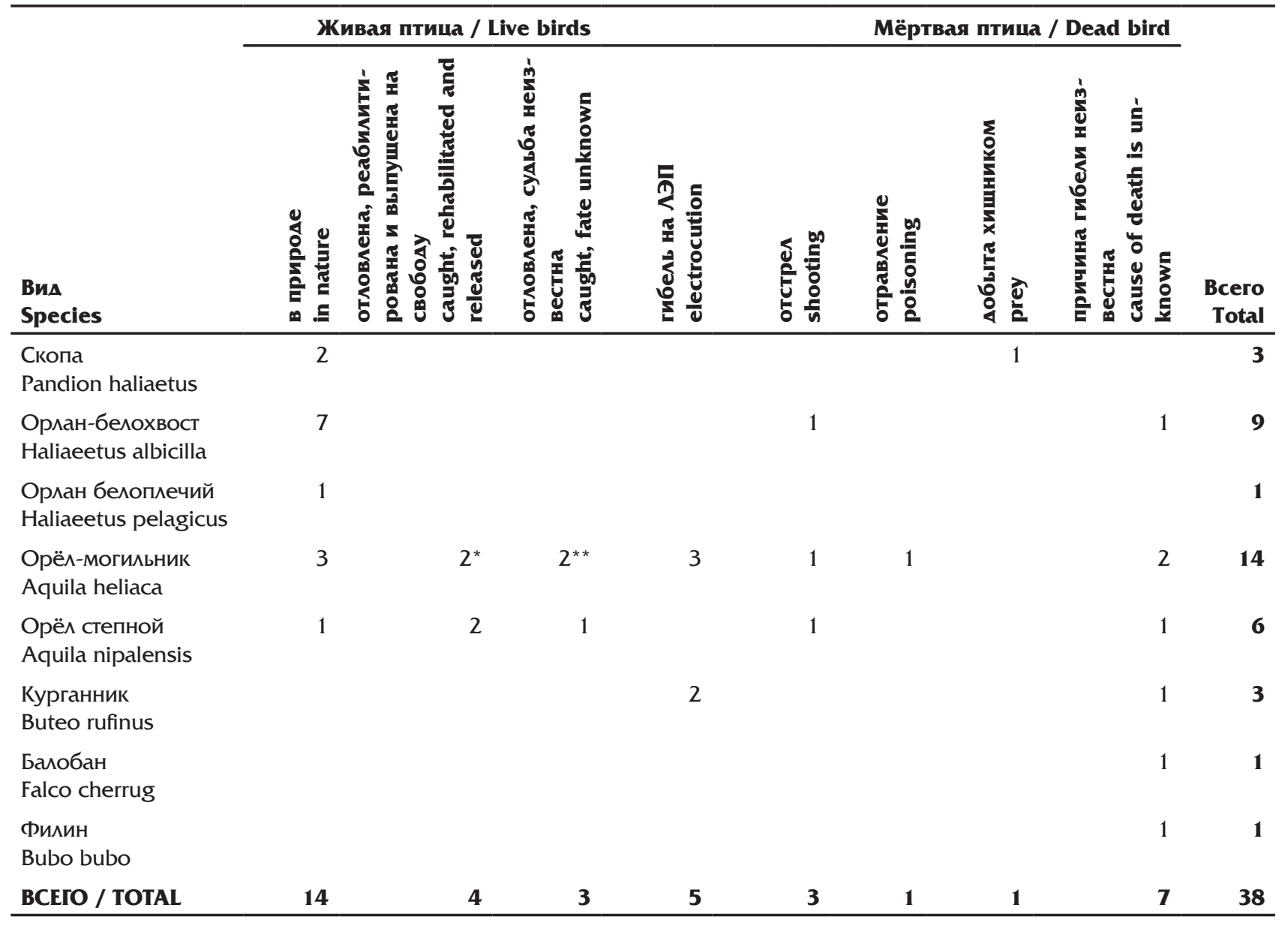

* - столкновение с АЭП и отравление / collision with power lines and posoning

** - одна птица с огнестрельным ранением / a one bird with a gunshot wound 


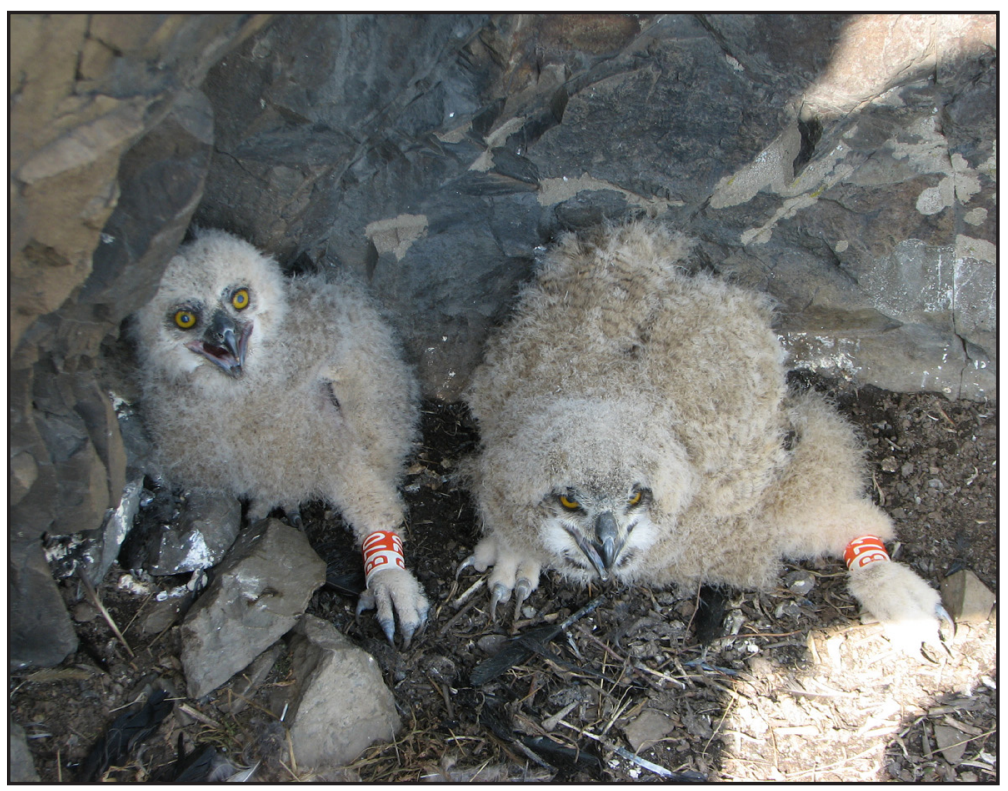

Птенцы филина (Bubo bubo) помеченные 28 мая 2014 г. в АитайСком крае. ОАин из птенцов погиб зимой в Казахстане. Фото С. Важова.

Nestlings of the Eagle Owl (Bubo bubo) ringed in the Altai Kray in 28 May 2014. One of the nestlings died this winter in Kazakhstan. Photo by S. Vazhov.
(1 случай), отстреляны - в России (Ставрополье) и Иране (раненный), погибли на гнездовом участке в Татарстане (3 случая), погибли и ранены на АЭП - в Татарстане (2 случая), Оренбургской области и в Иране (реабилитирован).

Похожую ситуацию мы видим, анаиизируя 6 случаев со степным орлом: $\Delta в е$ птицы были реабилитированы и выпушены в Иране и Кении, в арабских странах (в Саудовской Аравии и Кувейте) орлы были застрелены и отловлены соответственно, один погиб в Иране по неизвестной причине и один встречен живым в Аитайском крае относительно недалеко от места, гАе он вывелся.

В отличие от могильников и степных ор^ов, орланы из Татарстана, гле они, в основном, кольцеваиись, не улетают так малеко: 2 трупа были найдены на Украине и в Самарской области, а 7 птиц были сфотографированы на одном месте зимовки в УАьяновской области, при чём 4 из них были в возрасте от 1,5 $\Delta$ о 3 лет.

Обрашает на себя внимание случай гибели одного орлана - он был найден в нацпарке "Самарская Аука" на окраине города Жигулёвска, о его находке были информированы орнитологи Самарского отделения Союза охраны птиц России и сотрудники нац. парка, но труп орлана так и оставаися лежать, совершенно ненужный орнитологам и природоохранным организациям Самарской области, хотя о нём регулярно сообшали разные местные жители и посетители нац. парка. В итоге труп разложился, а причина гибели птицы так и не была установлена. Хотя некоторые респонденты сообшами о том, что птица была застрелена, этот фракт так и остался неподтверждённым.

Статистика по Аругим видам пока не такая богатая, однако, можно проследить похожие тенденции, описанные выше. $\Delta$ ве скопы были сфотограсрированы в Израиме и Аатвии и одна была добыта хишником ешё птенцом. Три курганника были найдены мёртвыми в России, недалеко от мест обитания, в т.ч. Ава погибли на АЭП.

Возврат балобана также весьма интересен: молодая птица прожила от момента кольцевания 3,5 месяца, улетела из Тувы на Телецкое озеро (Республика Алтай), гле погибла по неизвестной причине.

Найденный в Казахстане труп филина из Алтайского края подтверждает тот факт, что молодые филины ( $\Delta$ о года) Аостаточно широко разлетаются, прежде чем осесть на одной гнезАовой территории - этот улетел на 129 км за полгода.

О направлении миграции и местах зимовок разных видов можно сказать следуюшее.

Азимуты, по которым удалились от своих гнёзд на Средней Волге орланы-бе^охвосты, показывают юго-западное направление миграции - все, как Аальняя находка в Украине, так и ближние возвраты из Пензенской и Ульяновской областей, кишь подтвержАают генеральное юго-запацное направление миграции молодых птиц. Большая часть наблюдений окольцованных орланов-белохвостов помучена с места зимовки этих птиц близ Новоульяновска Ульяновской области (Россия). Учитывая отсутствие повторных наблюдений на зимнем скоплении одних и тех же окольцованных птиц, можно предполагать, что в зимний период происходит постоянное Авижение птиц и

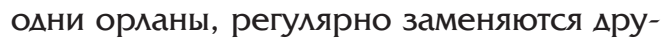
гими, за счёт чего подАерживается еАиновременная численность скопления $\Delta$ о сотни особей, но реальная численность птиц, проходяших через эту точку в ходе зимних кочёвок может быть на порядок большей (см. Бородин и Ар., 2015; Пчекинцев, Шашкин, 2015).

В очередной раз методами кольцевания подтверждена область зимовки мия орловмогильников Волго-Уральской популяции в странах Аравийского полуострова и восточной Асрики, выявленная ешё Б.У. Мейбургом (Meyburg, 2015) методом телеметрии. Подтверждена и предполагаемая ранее миграция на Аравийские зимовки некоторой части орлов-могильников, гнездящихся в российской части 
Аитая, большая часть которых зимуют в Пакистане и Индии (рис. 6). Аоказанный фракт пересечения на Аравийских зимовках орлов могильников из популяций Волго-Уральского и Алтае-Саянского регионов косвенно может указывать на обмен генами межАу этими популяциями, за счёт увлечения алтайских птиц с мест зимовки на места гнездования в Волго-Урамьский регион и наоборот. Последнюю точку в этом вопросе могут поставить молекулярно-генетические методы.

На основании двух находок в Иране алтайских степных орлов, относяшихся к восточному подвиду A. nipalensis nipalensis из гнезАовой группировки Юго-Восточного Алтая, Аоказана миграция особей этого подвила по Асрро-Евразийскому миграционному пути в область зимовки западного подвида степного орла $A$. nipalensis orientalis. Эта информация позволяет по-новому взглянуть на факты гнезАования крупных степных орлов в горных районах Мугоджар (Актюбинская область, Казахстан) и южной оконечности Южного Урала (Оренбургская область, Россия) преимушественно в совместных парах с более мелкими птицами, характерными Аля A. nipalensis orientalis.

На основании двух возвратов от верхневолжских скоп в Израиле и Эритрее (см. рис. 4) можно предположить, что они зимуют в основном в Восточной Асррике. ОАнако регистрация годовамой скопы из Аарвинского заповедника на Балтике (в Аатвии) весной говорит о том, что, возможно, какая-то часть верхневолжских скоп всё же зимует в Запацной Асрике, гАе находятся массовые зимовки скоп, гнездяшихся в Финляндии (Saurola et al., 2013), откуда они и мигрируют весной на Бамтику. Конечно, пока нет прямых возвратов из Запацной Африки, это мишь предположение, но подожАём Аальнейших результатов кольцевания и GPS/GSM телеметрии, которые прольют свет на Аанную гипотезу.

По сообшениям респондентов о возвратах степных орлов, можно слелать вывод о нежелательности использования крылометок, мия мечения этого редкого вида, стре-

Поврежцённая крылометка на степном орле (Aquila nipalensis), реабимитированном в Кении. Фото 3. Гиббс.

Damaged wingtag on the Steppe Eagle (Aquila nipalensis) that was rehabilitated in Kenya. Photo Z. Gibbs. мительно сокрашаюшего численность. За гоА поступила инсормация о регистрации 6 птиц (4-х из которых удалось идентисрицировать) - и 3 из них они были помечены крылометками, несмотря на то, что доля степных орлов, помеченных крылометками, среди обшего числа помеченных птиц низка.

В Саудовской Аравии орёл с крылометкой был специацьно отстрелян, причём как сообшают СМИ, по разрешению госоргана в Эр-Рияле, в связи с приступом шпиономании - на птице исками израильский передатчик, но не нашли. Т.е. убили её по сути просто так.

В Кении степной орёл был травмирован в результате атаки пегим вороном (Corvus albus), пытавшимся оторвать с него крымометку. Орёл был подобран Аюдьми и Аоставлен в реабилитационный центр в Найроби, откуда был выпушен после реабилитации на свободу.

В Омане в результате стычки между степным орлом с крылометкой и орломмогильником, последний вырваи из крыла крылометку, явно повредив птице патагиум. Подобранная крылометка была вся в поврежлениях и без кода, что говорит о том, что она неоднократно подвергалась агрессивному воздействию.

Учитывая то, что крылометки явно ос^ожняют жизнь степным орлам при отсутствии более прогрессивной научной отАачи от этого метода, в сравнении с безопасным кольцеванием, следует вынести на обсуждение вопрос о необходимости использования крылометок мяя мечения степного орла в Аальнейшем. Вопрос о необходимости мечения крылометками уже поднимался на консеренции «Орлы Палеарктики..." и по результатам Аискуссии, в резолюции круглого стола "Методы мечения пернатых хишников (спутниковые и GSM передатчики, цветное кольцевание и т.п.)" было закреплено решение участников "С осторожностью использо-

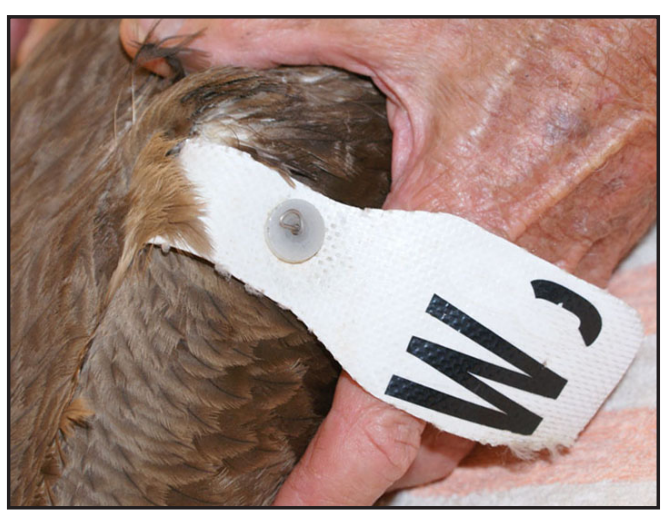




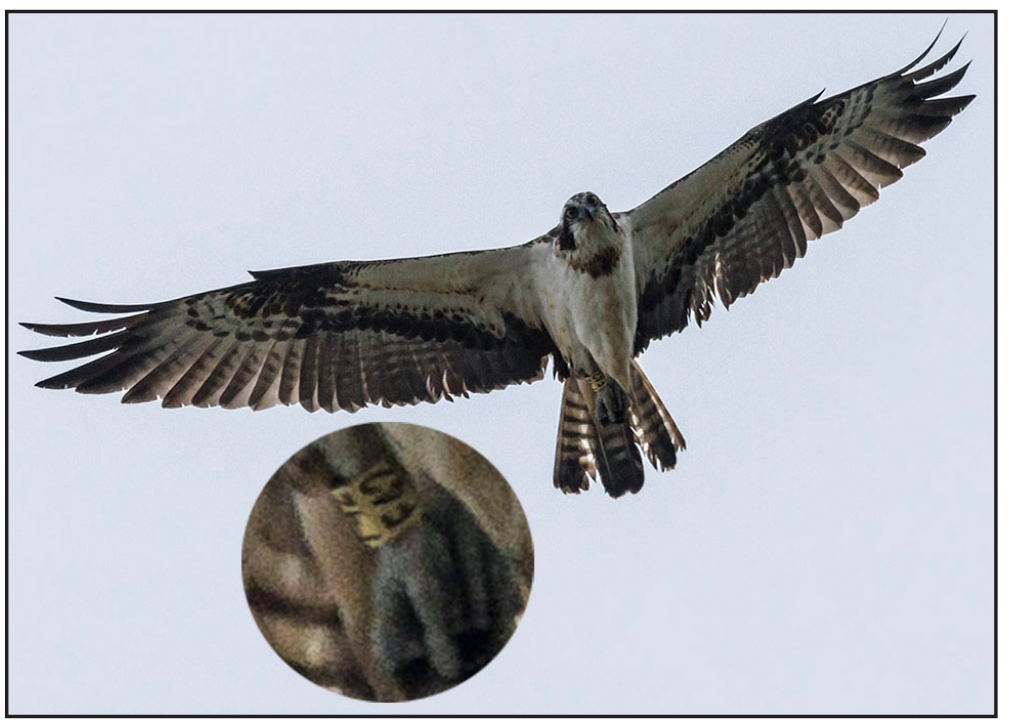

Скопа (Pandion haliaetus) из Аарвинского заповедника, сфотографированная 17 мая 2015 г. на побережье Балтийского моря в Аатвии. Фото А. Курочкина.

Osprey (Pandion haliaetus) from Darwin State Nature Reserve that was observed on the coast of the Baltic Sea in Latvia in 17 May 2015.

Photo by A. Kurochkin. вать крылометки в программах мечения, предварительно оценивая плюсы и минусы, а также эффективность этого метода». Также участники рекомендоваяи перенять опыт комег из Казахстана, используюших модисрицированную крылометку, которая нацевается на кисть и не травмирует крыло и более износостойкая (Итоги..., 2013).

В 2014 г. полтверждена недолговечность пластиковых колец на крупных орлах, таких как могильник и степной. В 10 случаях регистраций орлов из 29 пластиковые кольца ими были утеряны. Т.е. можно предполагать, что не менее $30 \%$ орлов за 3 года могли потерять кольца, причём, какая-то часть птиц, их потеряла уже в первый год. Отсюда можно слелать вывод, что орлов лучше кольцевать цветными амюминиевыми кольцами и курс на полный отказ от пластика в кольцевании ор^ов был взят правильный. Это не касается подорликов, ция которых потеря пластиковых колец пока не установлена.

\section{Закиючение}

Метод кольцевания хишных птиц цветными кольцами применяется в России бомее или менее масштабно только 3 года и уже с михвой оправдывает себя - массовость и Аоступность кольцевания, в частности, по сравнению с Аорогостояшими методами телеметрии, обеспечивают по многим вопросам более статистически $\Delta$ остоверный результат (конечно, не заменяя телеметрию в изучении Аругих важных тем). И это при том, что охват территории ешё очень небольшой - в сравнении с ареалами киючевых видов, охваченных кольцеванием.

К сожаиению, Ао сих пор во многих регионах России и Казахстана цветно- го мечения хишных птиц не ведётся, хотя кольцевание стандартными кольцами осушествляется. Стандартные кольца рассчитаны мишь на поимку птицы или нахождение погибшей птицы, так как прочитать полный код на таком кольце можно мишь держа птицу в руках. Цветные же кольца позволяют считывать код на живых птицах Аистанционно. В настоящее время при ценовой Аоступности фототехники высокого разрешения и телеобъективов, многие ^юбители птиц и простые фотографы могут получить высококачественные фотографрии окольцованных птиц. По этим фотограсриям легко прочитать не только цвет, но и код кольца. Распространяется в последнее время и практика наблюдения за птицами в оптические трубы, что также позволяет прочитать код на кольце и даже получить фотоподтверждение такого факта, ссотограсрировав птицу через трубу простым компактным фотоаппаратом или фотоаппаратом, встроенным в смартфон.

Цветное кольцевание является полезным методом при исследовании не только миграций, но также фрилопатрии, демографии, экологии, поведения и т.А. Использование цветных колец Аополнительно или вместо обычных метамлических колец значительно повышает эфреективность кольцевания как метода. Чтение кольца без необходимости отлова птицы уменьшает исследовательский пресс и снижает уровень стресса, наносимый исследователем. Более того, кольцо может быть прочитано разными исследователями относительно легко и много раз в течение жизни птицы, что позволяет собрать больше Аанных и улучшить исследования.

То же самое можно сказать и об аиюминиевых кольцах с Авойным прокрашенным кодом, которые имеют широкие перспективы внедрения в практику кольцевателей взамен обычных колец. На таких кольцах крайне важно наличие не только крупного читаемого кода, но и ясных и понятных Аанных о центре кольцевания, которые можно найти в сети Интернет. Аучше, если это будет ацрес сайта и/или электронной почты.

Опыт нашей программы показывает важность цифровой фотограсрии в наблюдении птиц, особенно мюбителями, так как это значительно увеличивает количество возвратов, а также важность нанесения на кольца алреса сайта, через который приходит основная инсормация о возвратах отловленных или погибших птиц.

В закиючении хочется отметить необхо- 
Аимость коорАинации межАу кольцевателями и согласования схем цветного мечения. Мы призываем всех, кто хочет вкиючиться в программу, обрашаться в Центр кольцевания хишных птиц мия оперативного согласования цветных схем мечения хишных птиц с координационными центрами в Европе и Азии.

\section{Благодарности}

Мы благодарны всем участникам программы кольцевания, а также респондентам, сообшившим информацию о встречах птиц, с нашими кольцами: Бородин Олег, Журавлёв Алексей, Зелеев Фарит, Курочкин Аиексей, Макогон Аиександр, Матвеев Сергей, Рзашев Тимур, Садыков Ильнар, Сергеев Иван, Тимофеев Михаил, Тоган Витаиий, Убушаев Батаар, Чупин Игорь, John Wright, Mohammadreza Enaloui, Nasir Yaqoob, Mike Barth, Michael Velasco, Sadegh Sadeghi Zadegan, Khalifa Al Dhaheri, Lavi Lilo, Yosef Kiat, Keisuke Saito, Fouad Itani, Zoe Gibbs, Ralph Buij, Simon Thomsett.

Особая благодарность Михаилу Тимофееву, благодаря которому получена интереснейшая инсормация о зимуюших в Ульяновской области орланах из Татарстана, и Роберту Еникееву, благодаря мастерству которого сотни орлов в России и Казахстане обзавелись нацёжными кольцами.

\section{Митература}

Бекмансуров Р.Х., Карякин И.В., Коваменко А.В., Карпов А.Г., Важков С.В., Шашкин М.М., Аевашкин А.П. Программа цветного мечения хишных птиц Российской сети изучения и охраны пернатых хишников (RRRCN): результаты 2012 года и перспективы. - Пернатые хишники и их охрана. 2012. № 25. С. 38-55. [Bekmansurov R.H., Karyakin I.V., Kovalenko A.V., Karpov A.G., Vazhov S.V., Shashkin M.M., Levashkin A.P. Programme on the Colour Ringing of Raptors of the Russian Raptor Research and Conservation Network (RRRCN): Results of 2012 and Prospects. - Raptors Conservation. 2012. 25: 38-55].

Бородин О.В., Корольков М.А., Тимофеев М.В., Ацамов С.Г. Изучение зимних скоплений орлана-белохвоста на территории Среднего Поволжья. Презентация докиала на V Межлународных Бутурлинских чтениях. - Российская сеть изучения и охраны пернатых хищников. 2015. URL: http://rrrcn.ru/archives/24510/2\#Borodin Аата обрашения 05.10.2015.

Итоги круглого стола «Методы мечения пернатых хишников (спутниковые и GSM передатчики, цветное кольцевание и т.п.)": Приложение 2 к Итогам Международной научно-практической консеренции "Орлы Памеарктики: изучение и охрана". - Пернатые хищники и их охрана. 2013. № 27. C. 16-18 [Outcomes of the roundtable "Methods of Marking of Eagles: Satellite and GSM Transmitters, Color Ringing, etc.”: Appendix 2 to Outcomes of the International Scientific and Practical Conference "Eagles of Palearctic: Study and Protection" - Raptors Conservation. 2013. 27: 16-18].

Карякин И.В. Результаты мониторинга популяции филина в ленточных борах Аитайского края, Россия. - Пернатые хишники и их охрана. 2014. № 29. С. 77-92. doi: $\quad 10.19074 / 1814-8654-2014-29-77-$ 92 [Karyakin I.V. Monitoring Results of the Eagle Owl Population in the Strip-shaped Pine Forests in the Altai Kray, Russia. - Raptors Conservation. 2014. 29: 77-92. doi: 10.19074/1814-8654-2014-29-77-92].

Карякин И.В., Николенко Э.Г., Шнайцер Е.П. Результаты мониторинга популяции балобана в Алтае-Саянском регионе в 2014 году, Россия. - Пернатые хишники и их охрана. 2014. № 29. С. 58-76. doi: 10.19074/1814-8654-2014-29-58-76. [Karyakin I.V., Nikolenko E.G., Shnayder E.P. Results of Monitoring of the Saker Falcon Population in the Altai-Sayan Region in 2014, Russia. - Raptors Conservation. 2014. 29: 58-76. doi: 10.19074/1814-86542014-29-58-76].

Николенко Э.Г. Проект «Орлы России»: итоги кольцевания орлов в 2013 г. - Пернатые хишники и их охрана. 2013. № 27. C. 264-270. [Nikolenko E.G. The Project "Eagles of Russia": Results of Eagle Ringing in 2013. - Raptors Conservation. 2013. 27: 264-270].

Пчелинцев В.Г., Шашкин М.М. Зимовка орлана-белохвоста в Среднем Поволжье. Презентация докиаца на V Международных Бутурлинских чтениях. - Российская сеть изучения и охраны пернатых хищников. 2015. URL: http://rrrcn.ru/ archives/24510\#Shahkin Аата обрашения 05.10.2015.

Meyburg B.-U. Satellite tracking of Eastern Imperial Eagles Aquila heliaca. - ResearchGate. 2015. URL: http://www.researchgate.net/publication/280742087 Date accessed: 10/08/2015 doi: 10.13140/ RG.2.1.1155.0564

Saurola P., Valkama J., Velmala W. The Finish Bird Ringing Atlas. Vol. 1. Finish Museum of Natural History and Ministry of Environment, Helsinki, 2013. 551 p. 